\title{
The application of resilience assessment-resilience of what, to what, with what? A case study based on Caledon, Ontario, Canada
}

\author{
Wai Ting Liu ${ }^{1}$
}

ABSTRACT. Resilience assessment can be used to determine major issues, stakeholders, vulnerabilities, and opportunities of a socialecological system to enhance resilience. A resilience assessment was conducted on the Town of Caledon, Ontario between 2010 and 2011 using the Resilience Assessment Workbook for Practitioners (version 1). The assessment explores the following three questions: Resilience of what? Resilience to what? Resilience with what? The answer to the first question describes the history, main issues, and stakeholders of the focal system. The answers to the remaining two questions describe potential resilience threats and assets, respectively. The assessment results include (1) identified resilience threats and assets of Caledon as a social-ecological system in the context of urban growth; (2) a cross-scalar study of Caledon in its ecological, social, and economic domains; (3) interviews with 26 community members on the topics of urban growth and resilience; and (4) recommendations for Caledon to enhance its resilience in face of urban growth pressures. The results reveal the significance of continual learning, engaged citizenship, and cross-scalar collaboration between governmental bodies. The assessment results also highlight some particular features that would enhance the resilience of Caledon, such as nurturing the health of agroecosystems, developing trade-off rules for conflict resolution, and treating low-impact urban development as an opportunity. This research provides a case study of resilience assessment of a community that undergoes a rural-urban divide. Emerging themes of resilience are identified. Research limitations and suggestions are presented at the end of this paper.

Key Words: conflicting interests; resilience assessment; resilience assets and threats; urban growth

\section{INTRODUCTION}

Geography, significant ecosystems, and local economy The Town of Caledon is the most northerly of the three municipalities in the Region of Peel in southern Ontario (Fig. 1). In size, it is larger than the other two municipalities - the City of Brampton and the City of Mississauga - combined (Region of Peel 2013). It covers over $700 \mathrm{~km}^{2}$ and is located northwest of the City of Toronto (Town of Caledon 2008a). Its population is 59,460 (Town of Caledon 2013). Caledon contains both the Oak Ridges Moraine and the Niagara Escarpment (Fig. 2), as well as the Credit, Humber, and Nottawasaga watersheds (Credit Valley Conservation (CVC) 2007, Town of Caledon 2008a). Caledon also constitutes over $84.9 \%$ of the forest cover in the Region of Peel (North-South Environmental Inc. et al. 2009: 35).

Fig. 1. Location of Caledon, marked by bold black lines, relative to other municipalities on the Oak Ridges Moraine. (Adapted from: Einstein (2005).)

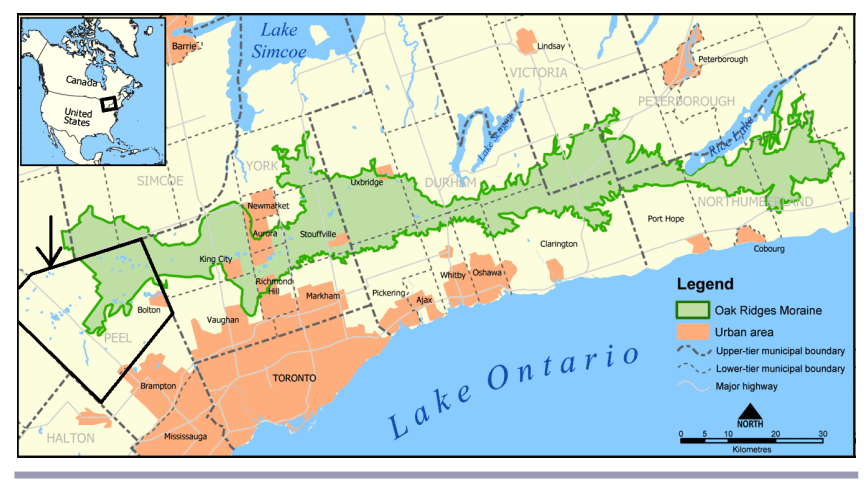

The Niagara Escarpment includes sites of geological significance and sources of southern Ontario's prime rivers, extending $725 \mathrm{~km}$ across Ontario (Niagara Escarpment Commission 2005; Fig. 3). The Niagara Escarpment was designated as a World Biosphere Reserve by the United Nations in 1990 and is protected under the Niagara Escarpment Planning and Development Act (1990) (Town of Caledon 2008a). The Oak Ridges Moraine covers about $24 \%$ of the Town of Caledon (Town of Caledon 2008b). The Moraine is one of the most significant landforms in southern Ontario (Fig. 1) and is the headwaters for over 65 river systems, acting as a recharge zone for aquifers, wetlands, and watersheds (Foster 2005, Diamond et al. 2002, Sparling et al. 2008). It is an interregional landform with highly significant biotic and cultural complexity, and extensive functions (surface drainage, groundwater, and terrestrial and aquatic ecology) (Igor 2002).

Although Caledon has the most active farmlands in Peel, a decreasing proportion of Caledon residents are engaged in agricultural activities; there is an increase in the local population who are urban workers or retirees (Chambers and Sandberg 2007, Baxter et al. 1999). Major economic activities in Caledon are industrial, commercial, and service based (Ross 1999, Town of Caledon 2009a). The three main sectors, which constitute $38 \%$ of local employment, are manufacturing, retail, warehousing, and transportation (Greenwood et al. 2010:5). More than half (50.4\%) of the local population commute to work outside of Caledon (Greenwood et al. 2010:15).

Background on the legislative framework and tiers of government Urban growth affairs in Caledon are highly influenced by the Province of Ontario. Provincial legislation, including the Planning Act (1990), Places to Grow Act (2005), the Greenbelt Act (2005), and the Oak Ridges Moraine Conservation Act (2001), are central to reconciling population increase, economic 
growth, and environmental protection across the Greater Golden Horseshoe area in southern Ontario (Fig. 4). A glossary of legislation is presented in Appendix 1. The Greater Golden Horseshoe area encompasses the regions of Durham, York, Peel (Caledon is one of the municipalities), Halton, Waterloo, and Niagara, the City of Toronto, and over a dozen of smaller cities (Ministry of Energy and Infrastructure (MOEI) 2010). The area is a very fast-growing urban region in North America. It is home to more than 7.5 million people (MOEI 2010), constituting approximately one-fifth of Canada's national population in 2010 (Statistic Canada 2013). The population in the Greater Golden Horseshoe was forecast to grow by 3.7 million people by 2031 (MOEI 2010). The province believes that uncoordinated growth will lead to negative effects, including traffic gridlock, urban sprawl, loss of farmland and habitats, and automobile dependence (MOEI 2010).

Fig. 2. Location of the Oak Ridges Moraine (light blue), Niagara Escarpment (light green), and other landforms in Caledon, Brampton, and Mississauga. (Source: North-South Environmental Inc. et al., unpublished manuscript, Fig. 3.)

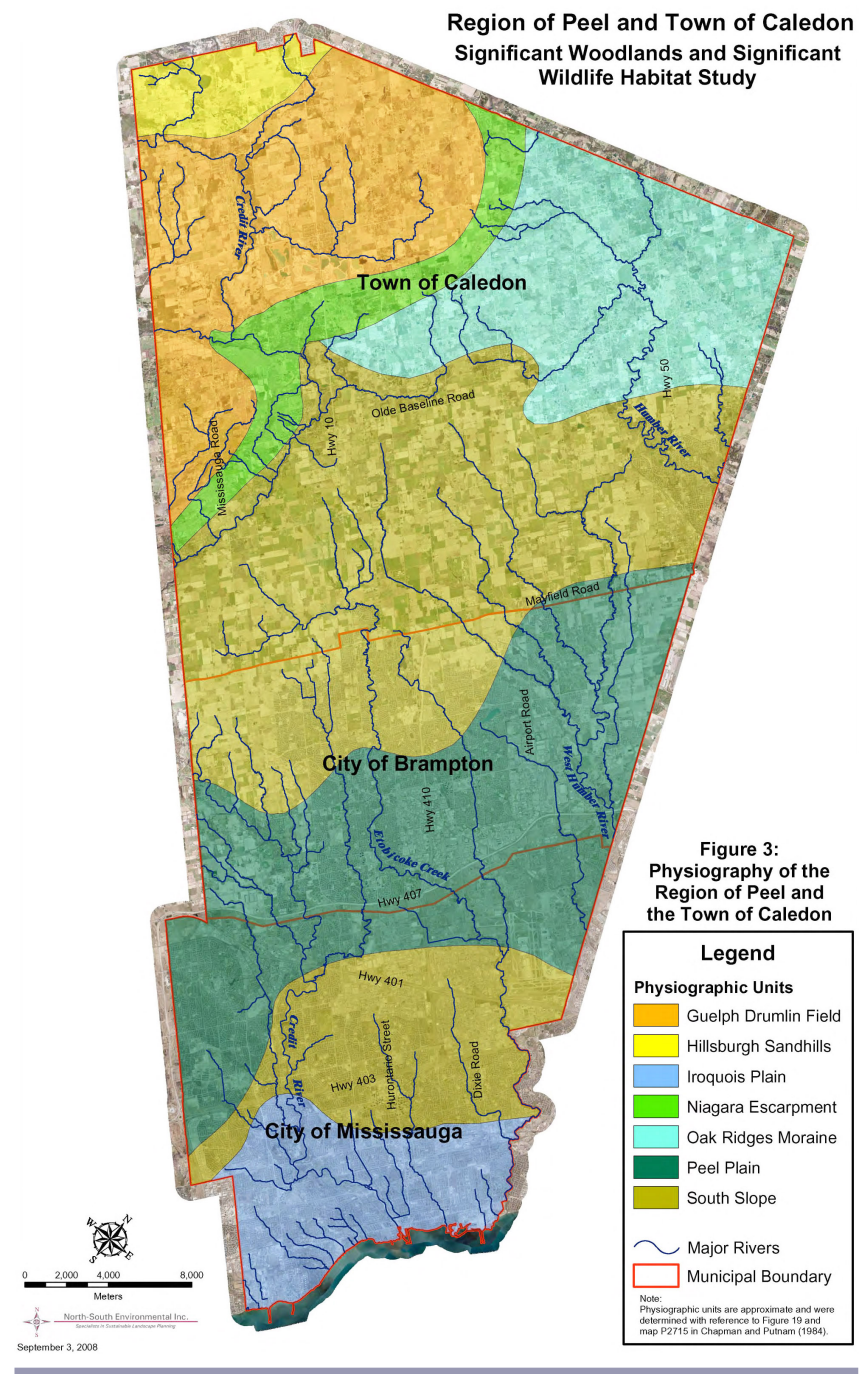

Fig. 3. Niagara Escarpment plan area in Ontario (Source: Niagara Escarpment Commission 2006).

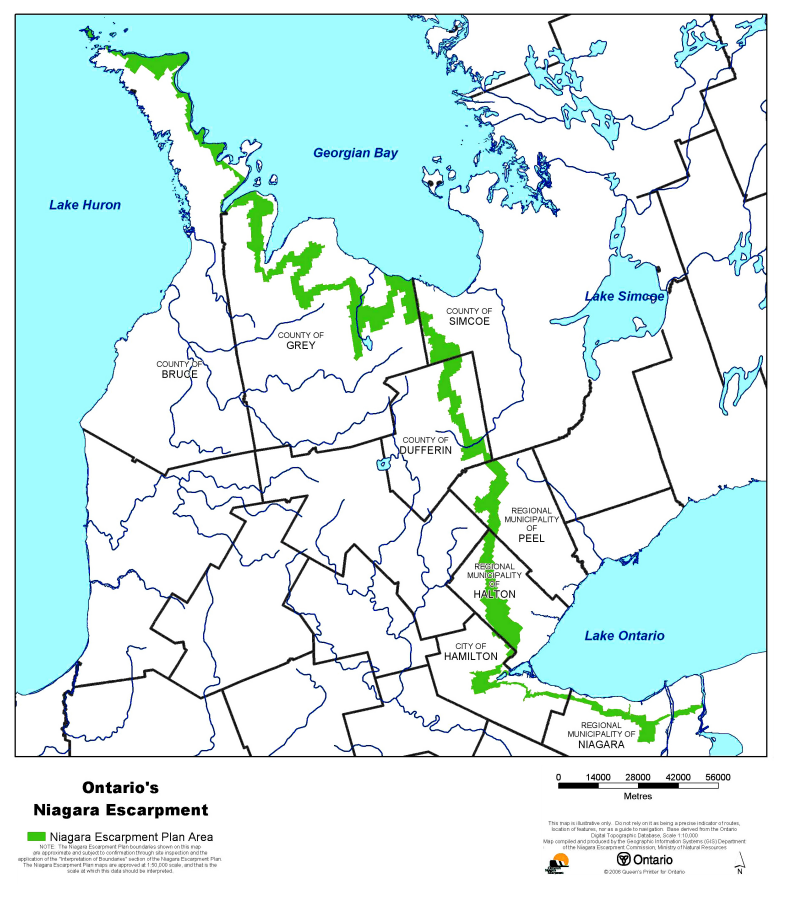

Fig. 4. The Greater Golden Horseshoe area. (Source: Ministry of Public Infrastructure Renewal (2006: Schedule 1).)

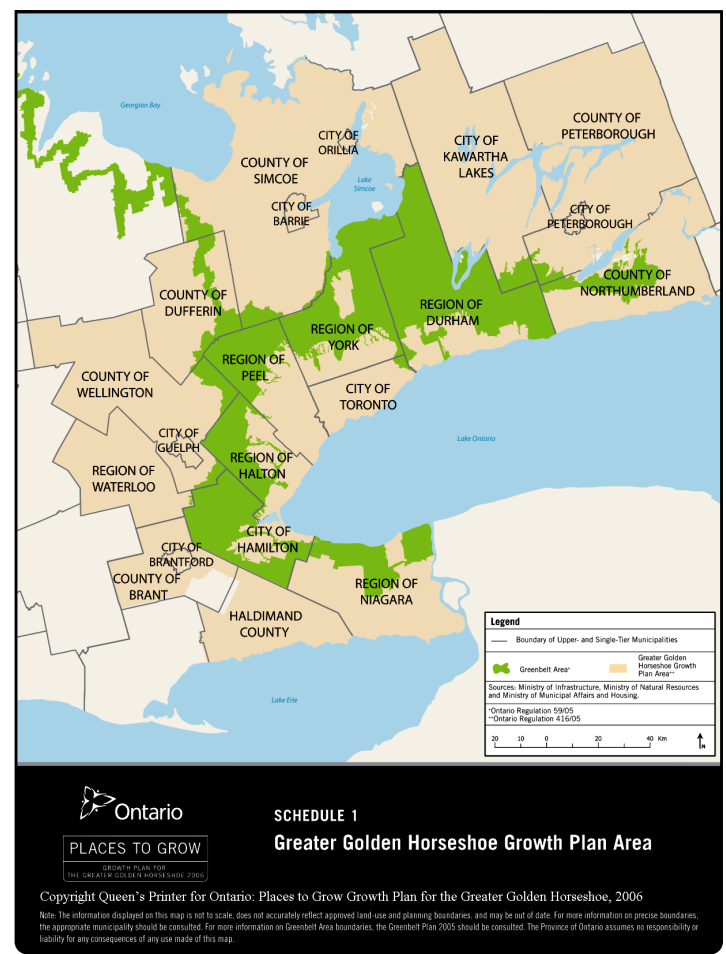


The Province of Ontario is the highest level of government that develops the legislative frameworks and policy directions for regional and municipal governments in rural and urban development affairs. The Ministry of Municipal Affairs and Housing (MMAH) is responsible for the Planning Act (1990), Places to Grow Act (2005), Oak Ridges Moraine Conservation Act (2001), and Greenbelt Act (2005). The aforementioned legislation requires a $10-\mathrm{yr}$ review mechanism. Under the Conservation Authorities Act (1946), conservation authorities are provincial bodies mandated to work with local governments in watersheds conservation (Toronto and Region Conservation (TRCA) 2007).

Regional governments are the middle level of government, sometimes also referred to as the "upper-tier" municipality, which is similar to a county. The regional governments are directed by official plans, which are long-term policy frameworks for decision making in areas such as urban planning, resource management, and social services (Region of Peel 2010b). Regional official plans are periodically reviewed to ensure conformity with provincial legislation and policies (Region of Peel 2014). The Regional Municipality of Peel Act (1973) created the regional municipality and three constituent municipalities: Caledon, Brampton, and Mississauga (Town of Caledon 2008a:4). Municipalities are the local governments that determine the strategic policy directions and details within the local context in conformity with the regional plans (Town of Caledon 2008a). The municipality of Caledon is responsible for land-use decisions through development approval and zoning that comply with the provincial legislation (Diamond et al. 2002, MMAH 2005). When there are disputes over planning and development, an independent tribunal called the Ontario Municipal Board (OMB) will hear applications and appeals to settle disputes.

Ontario's Planning Act (1990) details the provincial interest and municipal regulatory powers in land use (Hanna et al. 2007). Key concepts in the provincial interest statement include ecological functions and natural connections (Diamond et al. 2002). The Oak Ridges Moraine Conservation Act (2001) serves to protect natural heritage and ecological functions of the Moraine (Province of Ontario 2006). The objective of the Greenbelt Act (2005) is to protect 1.8 million acres of agricultural land and some environmentally sensitive areas around the Greater Golden Horseshoe, including the Oak Ridges Moraine and Niagara Escarpment (MMAH 2005).

The Places to Grow Act (2005) was passed to work in conjunction with the Planning Act (1990), the Oak Ridge Moraine Conservation Act (2001) and the Greenbelt Act (2005) to promote "Smart Growth" in Ontario (Ministry of Public Infrastructure Renewal 2006, MOEI 2010). The first growth plan is carried out in the Greater Golden Horseshoe area. The objective is to build "complete communities" that offer "transportation choices, accommodate people of all stages of life and have the right mix of housing...and easy access to stores and services" through intensification (MPIR 2006:13). The intensification target for Caledon is 50 people/jobs per hectare in the greenfield areas (Region of Peel 2010a).

\section{Challenges associated with urban growth in Caledon}

A major challenge for the Town of Caledon is to achieve its intensification target while meeting the needs of farming, aggregate extraction, and conservation. Caledon is facing urban growth pressures that can bring negative impacts on its ecosystems and social services (Caledon Environmental Advisory Committee (CEAC) 2006, CVC 2007, TRCA 2008c). Urbanization around the moraine has caused the loss and fragmentation of habitats, an increase of surface runoff, pollution and sedimentation of wetlands, and groundwater contamination (Matlack 1993, Dougan and Associates 2002, Diamond et al. 2002, CEAC 2006).

Caledon also faces conflicting interests among various groups including the landowners, farmers, estate developers, aggregate industry, and conservation authorities (Dore 2004, CEAC 2006, Johnson 2006, Chambers and Sandberg 2007, Mackenzie 2008, Markvart 2009). The town expects that it will have to accommodate close to 50,000 people by 2031 under the Places to Grow Act (2005), and its population forecast is 108,000 in 2031 (Town of Caledon 2009c:3, Town of Caledon 2014: Table 4-1). Caledon's 2013 population is 59,460 (Town of Caledon 2013). Much of its land is protected under the Oak Ridges Moraine and Niagara Escarpment legislation (CEAC 2006). By default, Caledon is under tremendous pressure to place new development on prime agricultural land (CEAC 2006). Caledon's Official Plan (OP) promotes a trinodal strategy that centralizes urban development in three rural services centers: Caledon East, Bolton, and Mayfield West. Nevertheless, the strategy does not guarantee the protection of farmlands and natural habitats that are unprotected under provincial legislation.

To deal with urban growth pressures, an understanding of Caledon as a system is needed for better growth management strategies (CEAC 2006, Purell 2009). In response to this need and the fierce rural-urban divide, the author has conducted a resilience assessment on the Town of Caledon. Resilience, in this assessment, refers to the abilities of linked social-ecological systems to learn, respond, adapt, and renew after disturbances (Holling 1973, Gunderson et al. 1995, Folke et al. 2002, Gunderson and Holling 2002, Armitage 2005, Walker and Salt 2006, Resilience Alliance (RA) 2007). It also refers to the ability of people to learn, adapt, and maintain a desirable state of socialecological systems (Gunderson et al. 1995, Folke et al. 2002, Gunderson and Holling 2002, Armitage 2005, Walker and Salt 2006, RA 2007). The primary question of this research is: based on resilience thinking, what factors threaten or enhance Caledon's abilities to respond and adapt to changes caused by urban growth as a linked social-ecological system?

\section{METHODS}

The Town of Caledon was used as a case study for the author to conduct a resilience assessment based on the guidelines laid out in the Resilience Assessment Workbook for Practitioners (version 1). The Resilience Assessment Workbook is authored by a team of researchers (Resilience Alliance (RA) 2007). The workbook has been revised to version 2 since 2010, but only version 1 was available when the author started the assessment. Whereas other resilience assessment tools focus on relatively specific topics (e.g., rural economies, hillslope communities, and Arctic water resources) (Table 1), the Resilience Assessment Workbook can be applied generally to linked social-ecological systems for the purpose of understanding a system from a resilience perspective (RA 2007). Therefore, the author has chosen to use the Resilience Assessment Workbook. 
Table 1. An overview of the resilience assessment framework and other frameworks

\begin{tabular}{|c|c|c|c|c|c|}
\hline $\begin{array}{l}\text { Projects/ } \\
\text { frameworks }\end{array}$ & Definitions of resilience & Resilience of what & Resilience to what & $\begin{array}{l}\text { Critical factors of } \\
\text { resilience }\end{array}$ & Target users \\
\hline $\begin{array}{l}\text { Resilience } \\
\text { Assessment } \\
\text { Workbook (RA } \\
\text { 2007) }\end{array}$ & $\begin{array}{l}\text { Resilience refers to the } \\
\text { capacity of a social-- } \\
\text { ecological system to } \\
\text { absorb shocks, } \\
\text { regenerate, and remain in } \\
\text { a desirable state; and } \\
\text { people's ability to adapt } \\
\text { and maintain resilience } \\
\text { of the system }\end{array}$ & $\begin{array}{l}\text { Social-ecological } \\
\text { systems }\end{array}$ & $\begin{array}{l}\text { Disturbances that can } \\
\text { flip the systems into an } \\
\text { alternate undesirable } \\
\text { state }\end{array}$ & $\begin{array}{l}\text { Vary according to the type } \\
\text { of system and the } \\
\text { identified desirable state. } \\
\text { Examples include } \\
\text { population of a species, } \\
\text { concentration of a } \\
\text { pollutant, and the ability } \\
\text { of a species to adapt }\end{array}$ & $\begin{array}{l}\text { Individuals, groups, and } \\
\text { institutions that want to } \\
\text { influence long-term } \\
\text { welfare of an integrated } \\
\text { social-ecological system }\end{array}$ \\
\hline $\begin{array}{l}\text { The Community } \\
\text { Resilience Manual } \\
\text { (CRPT 2006) }\end{array}$ & $\begin{array}{l}\text { "A resilient community is } \\
\text { one that takes intentional } \\
\text { action to enhance the } \\
\text { personal and collective } \\
\text { capacity of its citizens } \\
\text { and institutions to } \\
\text { respond to and influence } \\
\text { the course of social and } \\
\text { economic change" } \\
\text { (CRPT 2006:10) }\end{array}$ & $\begin{array}{l}\text { Social self- } \\
\text { sufficiency } \\
\text { Economic vitalities }\end{array}$ & Volatile markets & $\begin{array}{l}\text { People (beliefs, values, } \\
\text { attitudes) } \\
\text { Organizations (level of } \\
\text { collaboration) } \\
\text { Resources (the extent to } \\
\text { which the community } \\
\text { builds on local resources) } \\
\text { Community (the extent } \\
\text { and nature of community } \\
\text { participation in decision } \\
\text { making) }\end{array}$ & $\begin{array}{l}\text { Communities that face } \\
\text { economic difficulties, low } \\
\text { employment, and heavy } \\
\text { reliance on nonlocal } \\
\text { investment }\end{array}$ \\
\hline $\begin{array}{l}\text { Building Resilience } \\
\text { in Rural } \\
\text { Communities } \\
\text { (University of } \\
\text { Queensland and } \\
\text { University of } \\
\text { Southern } \\
\text { Queensland 2008) }\end{array}$ & $\begin{array}{l}\text { Resilience is "the } \\
\text { capacity of an individual } \\
\text { or community to cope } \\
\text { with stress, overcome } \\
\text { adversity, or adapt } \\
\text { positively to change" } \\
\text { (University of } \\
\text { Queensland and } \\
\text { University of Southern } \\
\text { Queensland 2008:3) }\end{array}$ & $\begin{array}{l}\text { Individuals and } \\
\text { communities }\end{array}$ & $\begin{array}{l}\text { Personal and social } \\
\text { stress/changes }\end{array}$ & $\begin{array}{l}\text { Social support } \\
\text { Positive outlook } \\
\text { Formal and informal } \\
\text { learning } \\
\text { Diverse and innovative } \\
\text { economy } \\
\text { Adaptive leadership }\end{array}$ & $\begin{array}{l}\text { Communities that are } \\
\text { interested in improving } \\
\text { their ability to withstand } \\
\text { shocks, such as drought, } \\
\text { unemployment, and a } \\
\text { lack of services }\end{array}$ \\
\hline $\begin{array}{l}\text { Incorporating } \\
\text { resilience in the } \\
\text { assessment of } \\
\text { inclusive wealth } \\
\text { (Walker et al. 2010) }\end{array}$ & $\begin{array}{l}\text { Resilience is the capacity } \\
\text { of a system to remain in } \\
\text { a given figuration of a } \\
\text { preferred state }\end{array}$ & $\begin{array}{l}\text { Productivity, values } \\
\text { of assets, and } \\
\text { associated social } \\
\text { welfare }\end{array}$ & $\begin{array}{l}\text { Risks associated with } \\
\text { irreversible changes in } \\
\text { the capacity of a system } \\
\text { to recover from } \\
\text { environmental shocks, } \\
\text { such as droughts }\end{array}$ & $\begin{array}{l}\text { The threshold of a critical } \\
\text { variable in the system (e.g., } \\
\text { rainfall determines crop } \\
\text { production) }\end{array}$ & $\begin{array}{l}\text { Community, business, } \\
\text { and government leaders }\end{array}$ \\
\hline $\begin{array}{l}\text { Assessment of } \\
\text { disaster resilience } \\
\text { capacity of } \\
\text { hillslope } \\
\text { communities (Chen } \\
\text { et al. 2008) }\end{array}$ & $\begin{array}{l}\text { Resilience refers to } \\
\text { capacity of hillslope } \\
\text { communities to minimize } \\
\text { and mitigate impacts of } \\
\text { geological hazards }\end{array}$ & $\begin{array}{l}\text { Hillslope } \\
\text { communities facing } \\
\text { geological hazards }\end{array}$ & Landslides & $\begin{array}{l}\text { Emergency response } \\
\text { capabilities } \\
\text { Warning and reporting } \\
\text { systems } \\
\text { Environmental conditions, } \\
\text { hazard of landslide, and } \\
\text { debris flow }\end{array}$ & $\begin{array}{l}\text { Community and } \\
\text { government leaders }\end{array}$ \\
\hline $\begin{array}{l}\text { Arctic Water } \\
\text { Resource } \\
\text { Vulnerability Index } \\
\text { (Alessa et al. 2008) }\end{array}$ & $\begin{array}{l}\text { Resilience is not } \\
\text { controlled by a single or } \\
\text { a few variables, but by } \\
\text { interactions of multiple } \\
\text { factors over a long period } \\
\text { of time }\end{array}$ & $\begin{array}{l}\text { Abilities of remote } \\
\text { Arctic communities } \\
\text { to respond to } \\
\text { changes in water } \\
\text { resources }\end{array}$ & $\begin{array}{l}\text { Disruptions caused by } \\
\text { changes in water } \\
\text { resources }\end{array}$ & $\begin{array}{l}\text { Physical supply and } \\
\text { infrastructure } \\
\text { Ability to perceive and } \\
\text { understand changes in } \\
\text { water supply } \\
\text { the use pattern of water }\end{array}$ & $\begin{array}{l}\text { Arctic communities } \\
\text { whose livelihoods } \\
\text { depend on the } \\
\text { watersheds }\end{array}$ \\
\hline
\end{tabular}

This research has relied primarily on academic, gray literature reviews, conference calls, and semistructured interviews. The author conducted interviews with 26 community members (Table 2) from diverse backgrounds to complement the findings from literature review. All interviews, except for two ${ }^{[1]}$, were transcribed manually. Note taking replaced transcripts for the latter two interviews. Interview results were sent back either electronically or through the mail to interviewees for comments. They were asked specifically to contribute ideas on how to enhance the resilience of Caledon in the face of urban growth pressures.
Furthermore, interview quotes were sent back to interviewees who had requested a review before the quotes were to be used.

Interviewees represented the governmental (11), nongovernmental (13), and private sectors (2). They included: individuals who have lived in Caledon for more than 10 years, municipal staff (local and regional), politicians, environmental group leaders, a social service representative, an aggregate industry representative, and a local property developer. The interviews began with 12 key informants. These informants were selected based on the recommendation of Ms. Debbe Crandall, who has been a Caledon 
Table 2. Interviewees' information by sectors

\begin{tabular}{|c|c|c|c|c|}
\hline Sectors & Subsectors & $\begin{array}{c}\text { Codes of } \\
\text { interviewees' } \\
\text { subsectors }\end{array}$ & $\begin{array}{l}\text { Number of } \\
\text { interviewees }\end{array}$ & Additional information about interviewees \\
\hline \multirow[t]{2}{*}{ Governmental (11) } & $\begin{array}{l}\text { Municipal Staff } \\
\text { (5 Local, } 1 \text { Regional) }\end{array}$ & MS & 6 & Four are not Caledon residents \\
\hline & $\begin{array}{l}\text { Politicians } \\
\text { (4 Local, } 1 \text { Regional) }\end{array}$ & PL & 5 & $\begin{array}{l}\text { Three town councillors are also farmers. One is } \\
\text { Caledon's mayor, and one is a regional politician. }\end{array}$ \\
\hline \multirow[t]{3}{*}{ Nongovernmental (13) } & $\begin{array}{c}\text { Environmental groups' } \\
\text { leaders }\end{array}$ & EG & 6 & $\begin{array}{l}\text { All are Caledon residents. One interviewee is also } \\
\text { a member of the Chamber of Commerce }\end{array}$ \\
\hline & Individuals & IN & 6 & $\begin{array}{l}\text { All individuals are residents of Caledon who } \\
\text { have lived in Caledon for more than } 10 \text { years. } \\
\text { They have knowledge about development and } \\
\text { growth of Caledon. One of them is a former } \\
\text { town staff member, and another is a former town } \\
\text { councillor. Four interviewees have been involved } \\
\text { in environmental initiatives. }\end{array}$ \\
\hline & $\begin{array}{l}\text { Social services } \\
\text { representative }\end{array}$ & SS & 1 & Caledon community services \\
\hline \multirow[t]{2}{*}{ Private (2) } & Aggregate industry & AI & 1 & Caledon resident \\
\hline & Local property developer & LPD & $\begin{array}{c}1 \\
\text { Total number of } \\
\text { interviewees: } \\
26\end{array}$ & Caledon resident \\
\hline
\end{tabular}

resident for over 35 years and was the founding chair of the Caledon Environmental Advisory Committee. Other interviewees were referred by the first 12 informants.

The interviews were semistructured and based on a set of preestablished questions. Respondents were allowed to deviate from the main question and talked about associated issues based on their experiences and expertise (Fontana and Frey 2000). This allowed greater flexibility in collecting a broader scope of indepth data (Fontana and Frey 2000).

\section{CALEDON AS A LINKED SOCIAL-ECOLOGICAL SYSTEM (RESILIENCE OF WHAT)}

Exploring the question "resilience of what?" involves identifying Caledon as a linked social-ecological system shaped by the people, biophysical environment, and history in the context of urban growth.

\section{History of Caledon as a social-ecological system}

Linked social-ecological systems contain "contextual factors in which local processes are shaped by larger-scale and ultimately global-scale processes" (Liu et al. 2007:1514). Ecosystems and social systems interact reciprocally across time and space (Liu et al. 2007). Studying resilience requires understanding how historical development shaped the current system (RA 2007). Historical timelines present major historical development of the Oak Ridges Moraine area (Fig. 5) and Caledon (Fig. 6). Nearly one-quarter (24\%) of Caledon is in the Oak Ridges Moraine area, and Caledon's history has been highly influenced by the development of the Moraine (Algonquin Associates 1993, MNR 1994, Historica et al. 1994, Ross 1999).

From the presettlement period to the early pioneers, the Moraine and Caledon were inhabited by indigenous populations (Historica et al. 1994). Pioneers started trading with the indigenous peoples in the 1600s, and they were attracted by water and land resources in Caledon (Historica et al. 1994, Ross 1999).

In the 1800s, European settlers engaged in extensive land clearing for subsistence and commercial agriculture in Caledon and the Moraine (Historica et al. 1994, Ross 1999). Sawmills and gristmills also flourished with the use of railways in Caledon (Ross 1999). Between 1890 and 1950, overproduction of wheat, soil erosion, deforestation, and the decline in water levels contributed to the agricultural decline and closures of mills in Caledon (Ross 1999:23). Conservation efforts began as early as the 1870s on the Moraine (Fisher and Alexander 1993). In Caledon, reforestation failed to restore the soil to its previous state (Ross 1999).

Between the 1880s and 1900s, intensive aggregate extraction took place in Caledon (Ross 1999, Chambers and Sandberg 2007). Caledon aggregate supplied materials for Toronto's Old City Hall, Ontario's Legislature buildings, and some of the University of Toronto's buildings (Ross 1999). Aggregate extraction continues today and has met public resistance (Johnson 2006, Markvart 2009).

During the First World War, tractors and electricity were introduced by the government into Caledon's agriculture (Ross 1999). In this period of time, $90 \%$ of the forest cover was cleared and almost $60 \%$ of the wetlands were drained in the Region of Peel for agriculture (Ross 1999:23). In the 1950s, in response to severe flooding and soil erosion, a number of conservation authorities were established to implement conservation of watersheds in Caledon and other areas (Ross 1999, CVC 2005). After the Second World War, rapid urbanization took place in Toronto (Ross 1999). In the 1970s, demands for Caledon to provide suburban residency and recreational sites increased (Ross 1999). 
Fig. 5. Historical timeline of the Oak Ridges Moraine areas (Sources: Fisher and Alexander 1993, Historica et al. 1994, McCarthy 2006)

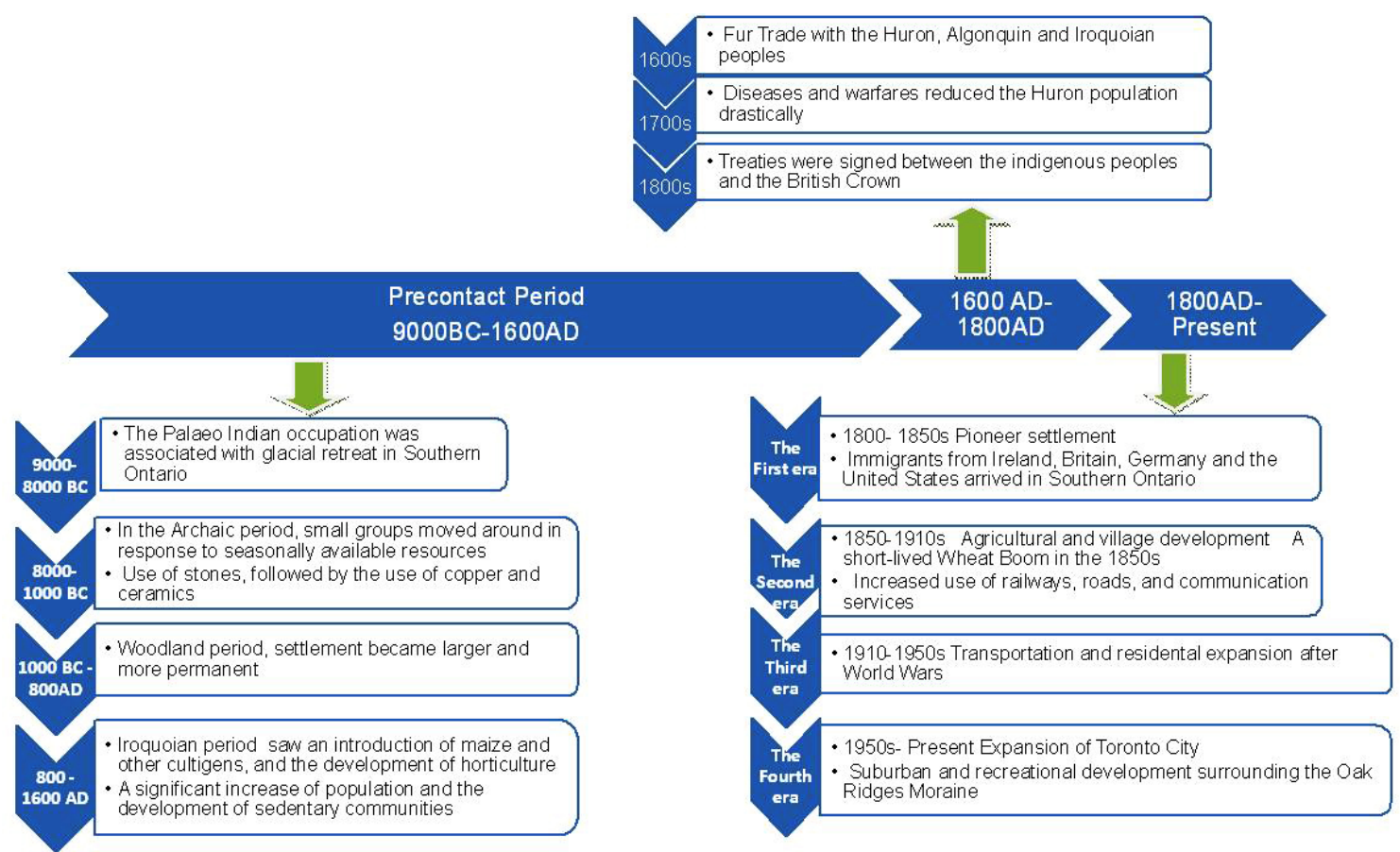

The Corporation of the Town of Caledon was created by provincial statute and the Regional Municipality of Peel Act on January 11974 (Town of Caledon 2008a). The first Official Plan of Caledon was approved in 1979 (Town of Caledon 2008a). In 2007, Caledon initiated its Official Plan conformity exercise to make the town's policies conform to provincial legislation, including the Greenbelt Act (2005), Places to Grow Act (2005), and Oak Ridges Moraine Conservation Act (2001).

\section{Stakeholders and main issues}

In the context of urban growth, there has been a fierce ruralurban divide in Caledon in the past decade. The divide involves complex issues concerning farming, conservation, urban intensification, and aggregate extraction. Major stakeholders include the Region of Peel, the municipality, farmers, conservation authorities, estate developers, the aggregate industry, local politicians, and citizen groups (Town of Caledon 2007). The Town Council of Caledon comprises five wards, each represented by a local councillor and a councillor from the Region of Peel, with the exception of Wards three and four, which share one local and one regional councillor. Politicians who represent the urban areas favor the expansion of the urban boundary, whereas those who represent the rural communities favor preservation of rural lands. There are farmers and landowners who favor development (Hilts and Watkins 2008), but the town and the conservation authorities (i.e., Toronto and Region Conservation Authority and Credit Valley Conservation Authority) intend to maintain more rural areas.

There has been intense disagreement between the estate developers and the Chamber of Commerce (local business representatives), who have actively lobbied to expand the urban boundary with higher urban density, and the Town, which has placed a ban on urban expansion of its urban center, Bolton (Gombu 2008). Millions of dollars invested by a company called Marotta could be lost because of the development freeze (Gombu 2008). The developer has also challenged Caledon's Official Plan at the OMB, which is an independent tribunal that settles disputes over land use and zoning in Ontario (OMB 2011).

The aggregate industry favors open access for extractions, whereas citizen groups and the town prefer stricter restrictions (Johnson 2006, Markvart 2009). Hearings over the disputes surrounding the establishment of new aggregate operations were held at the OMB. There is a strong tradition of preserving small communities and rural characteristics (Ross 1999, Lee-Macaraig and Sandberg 2007). Caledon has a number of environmental groups and a strong culture of stewardship (Lee-Macaraig and Sandberg 2007, Markvart 2009). A prominent group is known as The Coalition of Concerned Citizens (CCC), which has campaigned successfully against an aggregate operation (Johnson 2006, Markvart 2009).

Another important group is CEAC, which is made up of citizens and councillors. It advises the town on development and environmental issues (CEAC 2004). Another group called the Caledon Countryside Alliance has lobbied the Town to maintain its rural nature (Markvart 2009). Two other civil groups resisted the proposal of a landfill in Caledon, which finally led to its withdrawal (Baxter et al. 1999).

\section{A CROSS-SCALAR STUDY OF CALEDON- IDENTIFICATION OF POTENTIAL RESILIENCE THREATS AND ASSETS (RESILIENCE TO WHAT AND WITH WHAT)}

"A full resilience assessment must consider the cross-scale interactions of system components across boundaries" (RA 
Fig. 6. Historical timeline of Caledon, verified by the former and the working Heritage Officer of the Town of Caledon in 2011 (Sources: Algonquin Associates 1993, Ross 1999, Markvart 2009; interview with a former Heritage Officer of Caledon held on 10 September 2010).

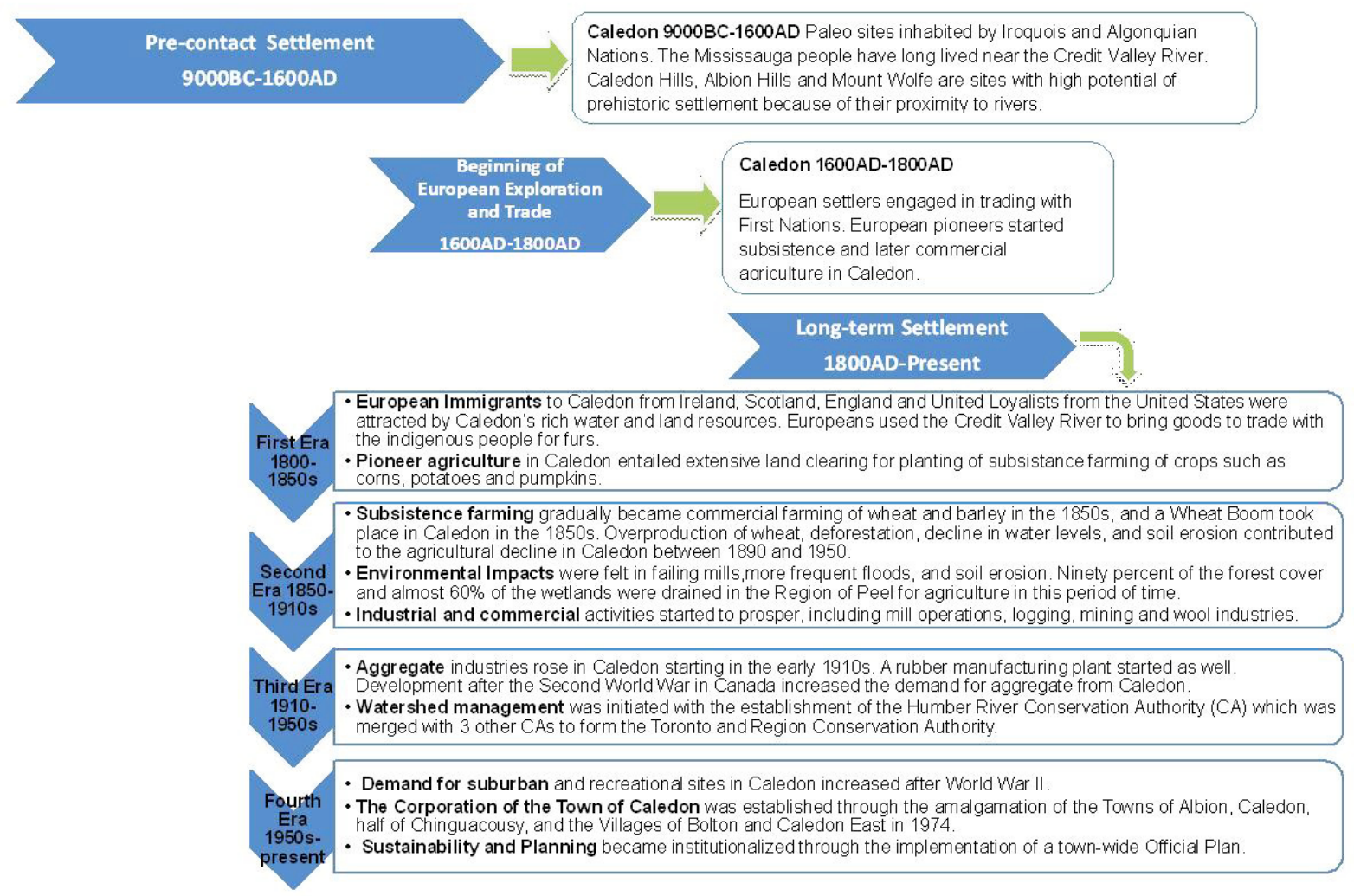

2007:12). The author has used the cross-scalar study to identify potential resilience assets ("resilience with what?") and threats ("resilience to what?") in the social, ecological, and economic domains. Resilience assets can potentially enhance the resilience of Caledon as a social-ecological system to learn, adapt, and renew after disturbances and maintain its desirable qualities in the context of urban growth. Potential threats to resilience can cause the opposite.

The study of the social domain (Table 3) focuses on legislation, policy directions, and their implications on land use and growth management in Caledon. By looking at legislation and associated policies, we can identify the links among governmental bodies across scales, as well as the role of nongovernmental groups.

The study of the ecological domain (Table 4) focuses on the Oak Ridges Moraine landforms and watersheds (Town of Caledon 2008a). The moraine was formed by a series of glacial advances and retreats (Fisher and Alexander 1993, Igor 2002). It contains headwaters draining southward to Lake Ontario and northward to Lake Simcoe, providing key ecological links across southcentral Ontario (Foster 2005).

The study of the economic domain (Table 5) focuses on economic activities driven by the provincial growth management policy. The following discussion will focus on the focal scale, the Town of Caledon. A summary is presented in Table 6.
Potential resilience assets and threats identified in the social domain in Caledon

A resilience asset identified in the social domain is in Caledon's Official Plan (OP). The OP is a document that states the strategic policy direction of land use, conservation, population growth, economic development, and agriculture. Although the Region of Peel has designated an intensification target to Caledon (Region of Peel 2010a), Caledon has maintained some decision-making power by requiring developers to submit environmental impact studies (EIS) and management studies (MS) (Town of Caledon 2008b). Specific conditions are placed on EIS and MS for the town to determine if development proposals benefit its ecosystems and communities. How effective these conditions are in maintaining the health of ecosystems of Caledon will require further studies. The requirements of MS and EIS can increase the town's capacity to negotiate with developers in reducing negative impacts of urban development on the biophysical environment. Keeping options open and the decision-making process flexible is important for nurturing resilience (Holling 2001, Folke et al. 2002, Walker and Salt 2006).

Another identified resilience asset is active civil groups, which nurture continual learning and self-organization (Oak Ridges Moraine Foundation (ORMF) 2003, 2009, Save the Oak Ridges Moraine Coalition (STORM) 2007, Oak Ridges Moraine Land Trust 2009). Networking among citizens allows knowledge sharing and learning, which is key to nurturing resilience (Lee 1993, Folke et al. 2002, 2003, RA 2007). In the context of growth management, 
Table 3. Scales in the social domain of Caledon in the context of urban growth

\begin{tabular}{|c|c|}
\hline Scale & Description \\
\hline Larger & $\begin{array}{l}\text { Government level } \\
\text { Ontario Municipal Board (OMB), Ministry of Municipal Affairs and Housing (MMAH), and Ministry of Infrastructure Renewal } \\
\text { Provincial legislation, such as Places to Grow Act, Greenbelt Act, Oak Ridges Moraine Conservation Act and Niagara Escarpment Planning } \\
\text { and Development Act }\end{array}$ \\
\hline Large & $\begin{array}{l}\text { Government level } \\
\text { Region of Peel, Regional Official Plan } \\
\text { Toronto and Region Conservation Authority } \\
\text { Citizen level } \\
\text { Environmental and moraine-wide groups, such as STORM (Save the Oak Ridges Moraine), Oak Ridges Moraine Land Trust, and Oak } \\
\text { Ridges Trail Association }\end{array}$ \\
\hline Focal & $\begin{array}{l}\text { Government level } \\
\text { Municipal governmental bodies such as Caledon Planning and Development, Environmental Progress Office, and Caledon } \\
\text { Environmental Advisory Council } \\
\text { Local watershed conservation authorities, such as the Credit Valley Conservation Authority } \\
\text { Citizen level } \\
\text { Major town-wide environmental groups, such as Caledon Countryside Alliance and Coalition of Concerned Citizens }\end{array}$ \\
\hline Small & $\begin{array}{l}\text { Government level } \\
\text { Villages, town's rural service centers } \\
\text { Citizen level } \\
\text { Local businesses, families residing in Caledon }\end{array}$ \\
\hline Smaller & $\begin{array}{l}\text { Government level } \\
\text { Individual officials such as town planners and town councillors } \\
\text { Citizen level } \\
\text { Individual members of environmental groups } \\
\text { Individuals who consume social and ecological services in the Town of Caledon }\end{array}$ \\
\hline
\end{tabular}

Table 4. Scales in the ecological domain of Caledon in the context of urban growth

\begin{tabular}{ll}
\hline \hline Scale & Description \\
\hline Larger & $\begin{array}{l}\text { The whole Niagara Escarpment, the whole Greenbelt, } \\
\text { and the whole Oak Ridges Moraine }\end{array}$ \\
Large & $\begin{array}{l}\text { Part of the Niagara Escarpment northwest of Caledon } \\
\text { Part of the Oak Ridges Moraine northeast of Caledon } \\
\text { Landforms protected under the Greenbelt Act in Caledon }\end{array}$ \\
& $\begin{array}{l}\text { Significant woodlands and habitats in Caledon } \\
\text { Focal }\end{array}$ \\
Credit River and Humber River watersheds \\
Creeks, kettle lakes, wetlands, woodlands, shrubs, trails, \\
parks, flora and fauna populations in Caledon \\
\end{tabular}

CEAC is another important group; it has contributed a great deal to the trinodal strategy (CEAC 2004). The strategy is central to Caledon's growth management policy by allocating residential and employment growth in three rural service centers. Another group, called the Concerned Citizens of Caledon (CCC), was formed in 1997 after an aggregate company proposed a quarry at
Table 5. Scales in the economic domain of Caledon in the context of urban growth

\begin{tabular}{ll}
\hline \hline Scale & Description \\
\hline Larger & Provincial smart-growth policies \\
Large & Regional intensification targets, employment land targets \\
Focal & $\begin{array}{l}\text { Caledon intensification targets, trinodal development } \\
\text { plan in Mayfield West, Bolton, and Caledon East }\end{array}$ \\
& Municipal agricultural policies \\
Small & $\begin{array}{l}\text { Developments in smaller communities, such as Terra } \\
\text { Cotta, Albion, and Caledon East }\end{array}$
\end{tabular}

Smaller Individual home businesses, farmers, and entrepreneurs

the Rockfort farm (Johnson 2006, Markvart 2009). The CCC hired professionals to conduct studies and represent them at the Ontario Municipal Board hearings (Johnson 2006). With its constant involvement, the Rockfort quarry application was eventually rejected in 2010 (OMB 2010).

Another identified resilience asset is Caledon's aggregate prioritization policy. In the context of urban growth, the Province has designated Caledon as an essential public source of aggregate. 
Table 6. A summary of potential assets and threats based on a cross-scalar study of Caledon

\begin{tabular}{lll}
\hline \hline Domains & Potential resilience assets & Potential resilience threats \\
\hline Social-municipal level & $\begin{array}{l}\text { Official Plan contains development approval mechanism that } \\
\text { keeps options open. Aggregate prioritization policy gives Caledon } \\
\text { some flexibility in the approval of aggregate extractions. Keeping } \\
\text { options open and decision-making process flexible is important for } \\
\text { nurturing resilience. }\end{array}$ & $\begin{array}{l}\text { The lack of indicators hinders continuous monitoring } \\
\text { and adjustments. } \\
\end{array}$ \\
& $\begin{array}{l}\text { Civil society groups nurture continuous learning and self- } \\
\text { organization }\end{array}$ & $\begin{array}{l}\text { places, reducing options for other towns. Examples } \\
\text { include the withdrawal of a landfill proposal and } \\
\text { aggregate extraction. }\end{array}$
\end{tabular}

Ecological-local ecosystems
Natural habitats facilitate the movement of biota, which enables species to renew and recolonize after disturbances.

Forests help reduce negative impacts of floods and heat island effects. Watersheds increase Caledon's ability to absorb negative impacts of water pollution and floods.

Economic-local economic policies/activities
Caledon trinodal strategy is conducive to the preservation of ecosystems. It also helps reduce Caledon's vulnerabilities to urban sprawl.

Caledon's agricultural policy can help preserve local ecosystems.
Urbanization poses threats to the health of the watersheds and, possibly, public health.

Aggregate operations cause stress to the environment and communities.

Loss of farmland reduces agroecosystems as well as some remnant natural habitats.

A lack of local jobs and public transit is very likely to lead to an increase in employment-driven commuting as the population increases, causing air, soil, and water pollution.
Caledon has maintained some of its decision-making power through an innovative aggregate prioritization policy (Chamber and Sandberg 2007, Markvart 2009). The prioritization policy categorizes lands into "Resource Areas," on which aggregate extraction is encouraged, and "Reserve Areas," which require a higher standard of approval (Town of Caledon 2008c, Markvart 2009). The policy gives the town more flexibility in deciding what type of aggregate operations is compatible with both ecological and economic interests (Town of Caledon 2008c, Markvart 2009). Flexible decision making is a key resilience feature (Holling 2001, Folke et al. 2002, Walker and Salt 2006).

An identified resilience threat in the social domain is a lack of indicators that can audit progress toward sustainability (Purell 2009). Monitoring allows learning and continual adjustment of policy to new situations, which is a key resilience feature (Holling 2001, Anderies et al. 2006, Walker and Salt 2006). The CEAC expressed the view that indicators were missing to assess the effectiveness of the OP in moving toward sustainability (CEAC 2006).

Another identified resilience threat is Caledon's "Not In My Backyard" (NIMBY) strategy. Johnson (2006), Chamber and Sandberg (2007), and Lee-Macaraig and Sandberg (2007) characterized local resistance in Caledon as NIMBY. This strategy succeeded in local initiatives such as the banning of a landfill and the Rockford Quarry (Baxter et al. 1999, Markvart 2009). Nevertheless, NIMBY may move local environmental impacts to other places, reducing the options and resilience of other municipalities.

\section{Potential resilience assets and threats identified in the ecological domain}

An identified resilience asset in the ecological domain is Caledon's natural habitats. Local landscape and watersheds provide links among diverse habitats, which can facilitate the movement of biota (Dougan and Associates 2002). For example, the Oak Ridges Moraine helps preserve natural corridors in Caledon, which facilitate migration and recolonization of species in an area after disturbances caused by fires or floods (Diamond et al. 2002, Dougan and Associates 2002). The ability to renew after disturbances is identified as a key resilience feature (Folke et al. 2002, Gunderson and Holling 2002, Walker and Salt 2006). Furthermore, Caledon has the highest percentage of forest cover in the Region of Peel (North-South Environmental Inc. et al. 2009: 35). Forest cover contributes to the resilience of a system to withstand the impacts of flooding, air pollution, and heat island effects (North-South Environmental Inc. et al. 2009).

Another identified resilience asset in the ecological domain is Caledon's watersheds. The Credit River and Humber River watersheds provide Caledon with clean drinking water and diverse habitats that support air quality, tourism, and recreation (CVC 2007, TRCA 2008b). The CVC and TRCA reported that forests and wetlands cover in the watersheds assimilate runoff, improve water quality, and reduce the likelihood of flooding (CVC 2007, TRCA 2008c). Caledon has the highest flood threshold compared with surrounding cities (Lei 2009). Thus, watersheds contribute to the resilience of Caledon because they can enhance the system's ability to absorb negative impacts of flooding, air pollution, and water pollution.

An identified resilience threat in the ecological domain is urbanization. The CVC and TRCA recognize that urbanization poses a great threat to the health of the watersheds and, possibly, public health (CVC 2007, TRCA 2008b). Urban growth can cause the loss of habitats, an increase of surface runoff, pollution of wetlands and groundwater (Matlack 1993, Dougan and Associates 2002, Diamond et al. 2002, CEAC 2006). 
Another identified resilience threat is the loss of farmland, leading to a reduction in agroecosystems and remnant natural habitats in Caledon. Agroecosystems are agricultural productions understood in relation to ecosystems' structures (e.g., trophic levels) and dynamics (e.g., nutrient cycles), and the productions' inputs (e.g., fertilizers) and outputs (e.g., runoff) in ecosystems (Gliessman 1998). Agriculture and farmers are important players in the preservation of natural resources, such as water, air, soil, and biodiversity (Sparling et al. 2008). Caledon's unprotected agricultural land, known as the "White Belt," constitutes $70 \%$ of Caledon's prime farmland (Mackenzie 2008:79). The prime farmland contains fertile soil and has been the most productive agricultural farmland in the Toronto region (Mackenzie 2008). This prime agricultural land in the White Belt will attract urban development, and farmers are very likely to sell their lands to developers for big financial gains (Hilts et al. 2008).

It is noteworthy that agriculture has brought negative impacts to the biophysical environment. These impacts include soil erosion, as well as water and soil pollution caused by livestock manure and the use of chemicals in the Region of Peel (Region of Peel 1998). Some of these negative impacts have been reduced by conservation tillage, no-till cropping, and crop rotation (Region of Peel 1998). The Region of Peel, in partnership with conservation authorities, has tried to reduce water contamination and enhance the health of agroecosystems by funding voluntary projects such as alternative pest management, manure management, runoff control, and soil fertility management (Peel Agricultural Advisory Working Group (PAAWG) 2011, 2012). Some farmers and landowners in Caledon have participated in the program (CVC 2011, 2012). There is a steady increase in the projects (PAAWG 2011, 2012). Nevertheless, sustainable agricultural practices still need to be much further expanded in Caledon to address water and soil pollution in the agricultural sector.

Lastly, an identified resilience threat is aggregate operations, also known as quarries or pits. Aggregate resources such as gravel, sand, and granite are nonrenewable raw materials (Markvart 2009). One major reason for the increased demand for aggregate resources is urban development. As urban development takes place, aggregate resources are needed for the construction and maintenance of road systems and buildings (Markvart 2009). Aggregate operations in Caledon involved mining, excavation, and transportation of aggregate (Johnson 2006, Markvart 2009). Aggregate operations have caused damage to vegetation, habitats, and watersheds (Centre For Spatial Economics (C4SE) 2009, Markvart 2009). The cumulative effects of aggregate operations can move parts of Caledon into an undesirable state (e.g., drinkable watershed into undrinkable watershed; natural habitats into open pits).

\section{Potential resilience assets and threats identified in the economic domain}

Caledon's intensification strategy, also known as the trinodal strategy, is identified as a resilience asset in the economic domain in the context of urban growth. The trinodal strategy allocates residential and business growth in three Rural Services Centers (Town of Caledon 2008c, 2009a, 2009b). Intensification can maximize transportation links, labor pool, and servicing systems (Town of Caledon 2008c). It can reduce Caledon's vulnerability to high financial and environmental costs of urban sprawl (MMAH 2005, MPIR 2006). It should be noted that the trinodal strategy, however, does not prevent urban development on some prime agricultural lands in Caledon.

Another identified resilience asset in the economic domain is Caledon's agricultural and rural policy, also known as the Official Plan Amendment 179 (OPA 179) passed in 2003. Under the OPA 179, Caledon has committed to supporting businesses associated with farming operations, such as wineries, farm markets, carpentry, and bed-and-breakfasts in order to produce healthy food and value-added products for local markets (Town of Caledon 2009e). In 2007, Caledon's Town Council passed a motion to express its interest in Alternative Land Use Services (ALUS). The ALUS approach is a distinct farm support program that provides financial compensation to farmers for their ecological goods and services to preserve agricultural lands (Mackenzie 2008). Ecological goods and services include water filtration, flood attenuation, biodiversity, and carbon sequestration. These policies can enhance functional and response diversity in local ecosystems, which is critical to the resilience of a social-ecological system (Folke et al. 2002, Walker and Salt 2006). It should be noted that the ALUS has not yet materialized in actual executions of programs in Caledon.

An identified resilience threat in the economic domain is the increase of employment-driven commuting as the population increases. In Caledon, $50.4 \%$ of the population commutes outside the community to work on a regular basis because of a lack of local employment and public transit (Greenwood et al. 2010:5). There have been significant job losses during recessions between 2007 and 2009 in three main local sectors: manufacturing, retail, warehousing and transportation (Greenwood et al. 2010). It is very likely that people will have to drive to work outside of Caledon as population increases.

Increased motor vehicle emissions can cause water, air, and soil pollution, and its toxic pollutants can damage aquatic and terrestrial ecosystems, particularly sensitive species (TRCA 2008a). The cumulative effects of urban growth, such as vehicle emissions, an increase of surface runoff and water contamination can reduce the resilience of Caledon's ecosystems to adapt and remain in a desirable state.

\section{INTERVIEW RESULTS-CALEDON RESILIENCE THREATS AND ASSETS (RESILIENCE TO WHAT AND WITH WHAT)}

The cross-scalar study of Caledon relies mainly on literature review. This raises two questions. How do people in Caledon view their abilities to respond to changes caused by urban growth? Is the concept of resilience relevant to their concerns? This research attempts to answer these questions through interviews with community members (Table 2). The interviews were attempts to gain qualitative insights from various stakeholders. They were not surveys that generated statistical significance. Interviewees were asked to describe Caledon's general features, including natural heritage, history, local economy, political climate, and people's livelihoods. Interviewees also discussed personal and other people's views on urban growth issues. They highlighted different aspects of urban growth issues because of different occupations and backgrounds. 
Interviewees were also asked to describe assets for and threats to a desirable Caledon. The information shed light on what a desirable social-ecological system looks like if resilience is to be nurtured in Caledon. According to interviewees, desirable qualities included natural landscape and heritage (10), engaged citizens (6), rural character with urban benefits (5), family roots (3), small town character (2), and a caring municipality (1). Some sample interview quotes about desirable qualities of Caledon are presented in Appendix 2. The author analyzed the assets and threats mentioned by interviewees from a resilience perspective. The results were then analyzed with the cross-scalar study.

\section{Resilience assets identified by interviewees in Caledon in the context of urban growth}

The resilience assets identified are: strong local civic engagement and volunteerism (15), participatory planning and solid citizenmunicipality relationship (8), low-impact urban development as an opportunity (8), diversified agriculture (5), provincial conservation policies (5), and municipal environmental leadership (5). Appendix 3 presents a list of interview quotes.

Fifteen interviewees commented that active civil society groups and volunteers were an asset as they brought knowledge and resources together to address social-ecological issues. An environmental group (EG) leader, EG1, observed that, "The strengths are again all those organizations that bring all the people together and help them to have a stronger voice about what's going on." Another, EG2, stated that, "Over the last 20 years, a group of people are there to protect and volunteer to preserve its ecological and environmental assets." A social service (SS) representative said that, "There is a lot of advocacy...people passionate about the community. So I think the community itself is a main strength." Municipal staff (MS) interviewee MS5 said that, "If you do something wrong, they [citizens] are certainly there to correct us. I guess the best example of it, we do have a committee, the Caledon Environment Advisory Committee...they will provide comments, support us, or correct us."

Eight interviewees mentioned that participatory planning and a solid relationship between citizens and the municipality were an asset. MS3 commented that "They [residents] get very involved in growth planning, and pushing Council to control growth."EG4 pointed out that, "The whole trinodal process, the whole master planning process, that all came out of Caledon Environmental Advisory Committee." EG2 said that, "I think that one of the strengths is the fact the relationship between the municipal government, whether it's politicians or staff, and citizenry. It's a pretty solid relationship."

Eight interviewees pointed out that low-impact urban development will be an asset for a desirable Caledon. Low-impact urban development includes features such as green roof, permeable surfaces, and better planning that allow residents to live and work within walking distances. MS3 stated that, "I think one of the great opportunities is that we are starting from scratch. We have the opportunity to do things right, not to have repeat mistakes...I think we have the opportunity to create a community that is based on good foundation of sustainability in growth management practices." MS5 said that, "To make Caledon resilient and sustainable is to protect our natural landscapes through sustainable rural/agricultural uses and balanced urban growth centers based on low impact design principles." Politician
(PL) 5 stated that, "If you can have people to work and live within a 10 and 15-minute range from home is a very strong, strong thing in our society today where people enjoy where they live and work. So I think again planning, planning has to do with a big part of that." PL3 believed that "Low-impact development is the way we have to start thinking... we can bring the population in. Let's think about how it fits into the nature around it..." Other benefits of urban development, according to interviewees, include the creation of compact communities and expansion of tax base for the municipality.

Five interviewees said that diversifying agriculture was an important asset for a desirable Caledon. Diversification of agriculture is about supporting value-added activities on farms such as cheese making and ecotourism. PL4 said that, "And they [Downy farm] also sell fresh turkeys, as you can see there, fresh turkeys, ducks in the winter time... There is a building in the back where they [Downy Farm] make their own wine, fruit wine, which they sell." MS1 highlighted the importance of "allowing more value-added on the farm... [rural] recreation can be supported with additional facilities." EG2 commented that, "They [several Caledon residents] have really big, big plans to really make this a multipurpose venture where they grow vegetables, they will have a CSA [Community Support Agriculture].” And this agricultural project, according to EG2, is to allow youth to learn about the connections between environmental issues and local food security.

Five interviewees referred to provincial conservation policies as an asset because the policies could protect the environment in Caledon against urban sprawl. EG4 said that, "And they [the municipality of Caledon] got the Niagara Escarpment Plan, the Oak Ridges Moraine Plan, and we got the Greenbelt Plan. So there is a large swap of Caledon that is pretty well protected." PL5 stated that, "I think really it's the policies of the government and the Official Plans uphold their policies, then I think that the ability of maintaining farming lifestyle can live in Caledon." Five interviewees pointed out that municipal environmental leadership was an asset because the government had invested time and resources in the trinodal strategy. MS3 mentioned that, "Council sees fit to maintain a fairly large planning department here for the size of the municipality. And so, they put a lot of resource into growth management."

\section{Resilience threats identified by interviewees in Caledon in the context of urban growth}

The resilience threats identified in interviews are: urbanization and population growth (16), disconnect between provincial legislation and people's livelihoods and stewardships (7), decline in agriculture (5), aggregate extractions (5), and fiscal challenges (3). Appendix 4 presents a list of interview quotes.

Sixteen interviewees expressed concerns about urbanization causing the loss of natural heritage, rural character, and agriculture in Caledon. MS2 mentioned that, "the provincial government will certainly be bringing a lot more industrial development through the southern...and bring with it huge transportation system along with that." MS3 pointed out that, "The Greenfield density target is kind of, the problem with it is top-down planning...It can force the residential density way, way up to 60,70 , or even 100 persons per hectare." PL4 observed that, "We continue to urbanize all the good agricultural land, we 
continue to green up the nonagricultural land as a compensator for urbanization...We continue, as society, to rely on more marginal lands' ability to produce more food. And in doing that, we are relying on more and more fertilizers, fairly dangerous methodology."

Seven interviewees commented that some provincial legislation can be a threat because the legislation lacked flexibility to allow for environmental innovations and agricultural diversification. EG2 could not build an education center because of zoning and conservation restrictions. EG2 said that, "I mean so much of the Moraine in Caledon is in the natural linkage. Really, you can't do anything there. There's no institutional use... I have always wanted to convert our family farm into a centre for learning." PL 2 mentioned that, "And it appears to me to be a group of bureaucrats sitting down at Queen's Park who have never been out in the countryside in their lives. And they don't really know what's going on. And therefore, they are making it much more difficult for these people [farmers] to make a living. They are selling [farmland]." PL3 said that, "And they [provincial officials] come up with regulations. The big thing is that they think because they are looking at textbook, they can think better. Why don't they ask people for their input?"

Five interviewees pointed out that agricultural decline was a threat because of the loss of farmland and employment. PL2 mentioned that, "Agriculture is suffering. It used to be our main industry in Caledon." PL4 said that, "So it's not only agriculture getting threatened, it's all the support industries, employment towards agriculture." Individual (IN) 1 stated that, "In Caledon, we have the top-grade farmland, but we have the only farmland left. It is getting huge development pressure from the east and from the south."

Five interviewees mentioned that aggregate extractions threaten their watersheds and rural heritage. EG5 said that, "And of course they [aggregate operations] are a threat to our water supply. And all the other things that came with that, the dust, many issues." PL4 explained that, "So the urbanization demands of Ontario makes the aggregate very attractive. So the laws of Ontario favor the gravel companies. The municipalities and the people who live within the area, and their municipal governments are always pitted against the gravel."

Three interviewees pointed out that Caledon faced fiscal challenges in long-term development because the town needed money to build servicing systems as the population increased. PL2 said that, "So when you get a developer who said I want to go right now, I am putting another 27,000 people in. Oh no, you are not. Because the 60,000 people over the next 10 years cannot afford to pay 86 million."

\section{DISCUSSION}

Based on the interview results and the cross-scalar study, the author has identified six emerging themes of resilience and recommendations accordingly. The themes and recommendations may provide insights for other municipalities that are affected in similar ways by urban growth issues in the Greater Horseshoe Area and elsewhere.
Theme 1: continual learning and adaptive decision making is a key resilience feature

Adaptive decision making allows for experimentation and adjustment of policies, which enhance resilience. This is illustrated in Caledon's prioritization aggregate and development approval policies (Table 6). Civil groups have played a significant role in promoting learning and adjustment between policies and socialecological conditions (Baxter et al. 1999, Lee-Macaraig and Sandberg 2007, Purell 2009, Town of Caledon 2009d, 2010) (Table 6). Fifteen interviewees commented that active civic engagement promoted continual learning among citizens and municipal staff (see interview results). This is illustrated in the Rockfort Quarry case, trinodal strategy, and other advocacy initiatives (Baxter et al. 1999, Johnson 2006, Lee-Macaraig and Sandberg 2007, Markvart 2009).

Henceforth, the author recommended that the Town of Caledon launch continual learning projects in the implementation of the OP, such as the trinodal strategy and agricultural policies, through an accessible communication platform (e.g., online interactive tool for public participation). Another important area is for the town to develop indicators or criteria to measure the effectiveness of its growth management policy in achieving intensification while maintaining its social and ecological capacities to adapt to changes caused by urban growth and to remain in a desirable state.

\section{Theme 2: nurturing healthy agroecosystems is a key resilience feature}

The loss of farmland is identified as a potential threat to resilience because of the subsequent loss of agroecosystems, remnant natural habitats, and employment opportunities (Table 6). The prime agricultural land in Caledon is highly susceptible to urban development (CEAC 1996, Hilts et al. 2008). Interview results also highlighted the importance of agriculture for local employment and ecosystems. The Region of Peel and conservation authorities have funded and launched sustainable agricultural projects in Caledon and other municipalities in order to build an ecologically sustainable and economically viable agriculture (PAWGG 2011, 2012, CVC 2011, 2012). The Town of Caledon also expressed an interest in ALUS, which financially rewards farmers for ecological goods and services, such as water filtration and biodiversity. A diverse local agriculture is also important to the resilience of Caledon because it supports an "eat local" rural economy that can withstand external market fluctuations (Greenwood et al. 2010).

Therefore, the author recommended that the Town of Caledon take a more active role in partnering with the Region of Peel and conservation authorities to give financial and technical support to farmers in adopting more ecologically sound agricultural practices, such as native species plantation and alternative pest management. The town can also give marketing support to farmers to strengthen a "eat local" economy. Furthermore, Caledon can implement ALUS pilot projects with local farmers. In the 10-yr review of Greenbelt Act (2005), the Town of Caledon can work with the Province and the Region to increase the flexibility of legislation to allow for agricultural operations, such as ALUS, that can enhance the health of agroecosystems. 


\section{Theme 3: a threat can be an opportunity}

The cross-scalar study and 16 interviewees have pointed out negative impacts of urban growth (Table 6). However, eight interviewees saw opportunities in low-impact urban development to implement sustainability and create compact communities. Therefore, the author recommended that Caledon use low-impact technologies (e.g., permeable pavement, green roof) to achieve intensification while reducing its negative impacts, particularly in the trinodal areas.

\section{Theme 4: a resilience asset can be seen as a threat}

In the context of growth management, a resilience asset can be seen as a threat to resilience. For example, civil groups help promote continual learning and address some negative impacts of urban growth (Baxter et al. 1999, Johnson 2006, Lee-Macaraig and Sandberg 2007, Markvart 2009) (Table 6). However, their NIMBY strategy can also reduce resilience of other municipalities by pushing the problems elsewhere (Johnson 2006, Chamber and Sandberg 2007, Lee-Macaraig and Sandberg 2007) (Table 6). Furthermore, five interviewees indicated that conservation policies were an asset for Caledon, whereas seven interviewees saw them as an impediment to environmental innovations and agricultural diversification (see interview results).

The implication of this finding is that Caledon needs to innovate ways to work with resilience assets that can be regarded as threats. The author recommended that Caledon develop trade-off rules to resolve conflicts and address situations where Caledon has to balance the need for urban intensification with natural conservation or the need for aggregate extractions with watershed protection. Some trade-off rules are presented in Appendix 5.

Theme 5: resilience of a focal system is influenced by other scales The cross-scalar study shows that Caledon has been heavily influenced by provincial and regional policies. A number of interviewees referred to provincial policies as a major influence on municipal planning. The author recommended cross-scalar collaborations between Caledon, the Region of Peel, and the Province of Ontario. Caledon shall bring local knowledge and concerns, particularly of those whose livelihoods depend on the land, to the region and province to implement conservation, agriculture, and urban growth policies.

\section{Theme 6: a clash of values}

Urban growth involves multiple parties and levels of government. The research results show that urban growth issues in Caledon are not only legislative issues. It is not a simple case of "bad urban growth" versus "good rural communities." The rural-urban divide represents a clash of values and expectations of a desirable community. A number of interviewees named this clash in different ways.

An environmental group leader, EG5, said that, “....and that's a real, real problem for Caledon. We are stuck in the middle of really strong, conflicting interests and strong lobby groups." EG2 raised that, "I don't think people know why they think growth is bad. I really don't. Is it a fear of their value system being invalidated by another value system?" PL5 observed that, "They have a typical right-wing conservative, entrepreneurial farmer, is going to have an ideology, he basically says get off my back...Then you get the people who are sort of on the left side who are very strongly proenvironment people." MS6 said that, "You know there are many people who resist growth in Caledon, just want Caledon to stay as small, rural municipality. And that's why they chose to live there. You know, there are people on the other side of that, who have the interest of seeing Caledon to grow for various reasons." IN6, who has lived in Caledon for more than 60 years, said, “... it's a just a question of takeover by the developers to make another Brampton with so many houses along the street. Should we do that? Or shouldn't we?"

Therefore, the author recommended that Caledon develop an integrated resilience plan for a desirable Caledon. This plan may contain the aforementioned recommendations. The plan should strive to tighten feedback loops between policies and socialecological changes caused by urban growth and resolve conflicts by involving stakeholders in defining a vision, implementing plans and assessing the results in an open and accessible manner.

\section{CONCLUSION}

This research provides a case study of resilience assessment that attempts to understand urban growth issues of a town as a socialecological system. The research provides insights for places in North America and elsewhere that are experiencing similar ruralurban divide from a resilience perspective. This research also provides insights into future review of important legislation concerning population growth and conservation, such as the Greenbelt Act (2005) and the Places to Grow Act (2005). The assessment also sheds light on concrete methods used to conduct a resilience assessment of complex issues. A research limitation was that the author has not analyzed in depth how resilience assets can address particular threats. Also, the author was not able to arrange interviews with the conservation authorities who are important stakeholders.

Future resilience assessments can explore how resilience assets in the ecological, social, and economic domains may mutually enhance each other and address threats to resilience. Future resilience assessments may also look further into desirable qualities of social-ecological systems such as sufficient livelihoods, access to social support and services, diverse employment, engaged citizenship, a culture of continual learning, and responsible stewardship of natural resources (Community Resilience Project Team (CRPT) 1999, Gibson 2006, University of Queensland and University of Southern Queensland 2008). Recognizing desirable qualities of social-ecological systems in the local context can help solidify resilience plans on an operational level.

Furthermore, an increase in the resilience on one scale does not necessarily promote resilience on another. This is illustrated in Caledon in the NIMBY strategy employed by its citizen groups. How to increase the resilience of a focal system without losing the resilience of the bigger social-ecological system continues to challenge resilience thinking practitioners. Being able to detect when smaller scales will bring proper sources of novelty to bigger scales or when bigger scales are imposing too many constraints on the system will be an important part of resilience research. Lastly, it will be beneficial for future resilience researchers to develop guidelines on the development and implementation of resilience plans to investigate what kind of resilience is desirable, for whom, and toward what purposes resilience is to be nurtured. 
Responses to this article can be read online at: http://www.ecologyandsociety.org/issues/responses. $\mathrm{php/6843}$

\section{Acknowledgments:}

The author thanks Professor Dan McCarthy, Professor Bob Gibson, and Ms. Debbe Crandall for their knowledge, reviews, and guidance. The author thanks Mr. Jonathan Chu for his insights and reviews. The author must thank Caledon's community members who have participated in the research and have shown great enthusiasm and knowledge for the well-being of their community.

\section{LITERATURE CITED}

Alessa, L., A. Kliskey, R. Lammers, C. Arp, D. White, L. Hinzman, and R. Busey. 2008. The Arctic water resource vulnerability index: an integrated assessment tool for community resilience and vulnerability with respect to freshwater. Environmental Management 42:523-541. http://dx.doi.org/10.1007/ s00267-008-9152-0

Algonquin Associates. 1993. Technical appendices. In Historica Research Ltd., Algonquin Associates, Michael McClelland Designs, and Commonwealth Historic Resource Management Ltd. 1994. A cultural heritage resources assessment study for the Oak Ridges Moraine area. Background study no. 7 to the Oak Ridges Moraine Area Planning Study. Oak Ridges Moraine Technical Working Committee, Caledon, Ontario, Canada.

Anderies, J. M, B. H. Walker, and A. P. Kinxzig. 2006. Fifteen weddings and a funeral: case studies and resilience-based management. Ecology and Society 11(1): 21. [online] URL: http:// www.ecologyandsociety.org/vol11/iss1/art21/

Armitage, D. 2005. "Adaptive Capacity and Community-Based Natural Resource Management" forum. Department of Geography and Environmental Studies, Wilfrid Laurier University, Waterloo, Ontario, Canada.

Baxter, J, J. Eyles, and S. Elliott. 1999. Something happened: the relevance of the risk society for describing the siting process for a municipal landfill Geography Annual, 81 B, (2): 91-109.

Caledon Environmental Advisory Committee (CEAC). 2004. CEAC report comments on the provincial discussion paper "Places to grow: a growth plan for the greater Golden Horseshoe." CEAC, Caledon, Ontario.

Caledon Environmental Advisory Committee (CEAC). 2006. Report 2006-02 A sustainable growth option for Caledon. CEAC, Caledon, Ontario.

Centre For Spatial Economics (C4SE). 2009. The potential financial impacts of the proposed Rockfort Quarry. Administration Department Chief Administrative Officer Report CAO-2009-001, schedule B. Prepared for the Town of Caledon. C4SE, Milton, Ontario. [online] URL: http://conestogowinterbourne.com/ROCKFORD $\% 20$ QUARRY $\% 20$ FINANCIAL $\%$ 20IMPACTS.pdf
Chambers, C., and A. Sandberg. 2007. Pits, peripheralization and the politics of scale: struggles over locating extractive industries in the town of Caledon, Ontario, Canada. Regional Studies 41(3): 327-338. http://dx.doi.org/10.1080/00343400600928319

Chen, S. C, J. W. Ferng, Y. T. Wang, T. Y. Wu, and J. J. Wang. 2008. Assessment of disaster resilience capacity of hillslope communities with high risk for geological hazards. Engineering Geology 98: 86-101. http://dx.doi.org/10.1016/j.enggeo.2008.01.008

Community Resilience Project Team (CRPT). 1999. The community resilience manual. Making Waves 10(4):10-14.

Credit Valley Conservation (CVC). 2005. Credit Valley Conservation watershed report card: a detailed summary on the ecosystem health of the Credit River watershed. CVC, Mississauga, Ontario, Canada. [online] URL: http://www.creditvalleyca.ca/ wp-content/uploads/2011/02/WRCard-Detailed.pdf

Credit Valley Conservation (CVC). 2007. Credit River water management strategy. CVC, Mississauga, Ontario, Canada. [online] URL: http://www.creditvalleycons.com/bulletin/resources. $\underline{\text { htm }}$

Credit Valley Conservation (CVC). 2011. Credit Valley Conservation presents Friends of the Credit awards to deserving farmers. CVC, Mississauga, Ontario, Canada. [online] URL: http://www.creditvalleyca.ca/news/story/credit-valley-conservationpresents-friends-of-the-credit-awards-to-deserving-farmers/

Credit Valley Conservation (CVC). 2012. Restoration project in the east Credit inspires tour participants. CVC, Mississauga, Ontario, Canada. [online] URL: http://www.creditvalleyca.ca/ source/2012/08/restoration-projects-in-the-east-credit-inspire-tourparticipants/

Diamond, M. J. Dougan, N. Helferty, E. Hodge, P. Niblett, M. Rose, and S. Rowe. 2002. Natural heritage systems in urbanizing settings: sustainable practices for the Oak Ridges Moraine. Save the Rouge Valley Inc. and the City of Toronto, Toronto, Ontario, Canada.

Dore, R. 2004. Implementing the Oak Ridges Moraine conservation plan: a case study of initial implementation experiences. Thesis, Department of Geography and Environmental Studies, Wilfrid Laurier University, Waterloo, Ontario.

Dougan and Associates. 2002. Save the Rouge Valley Systems Inc. natural heritage protection under OPA 129 performance evaluation. Prepared for SRVS and the City of Toronto. Dougan and Associates, Toronto, Ontario, Canada.

Einstein, N. 2005. Oak Ridges Moraine map. Wikimedia Commons. [online] URL: http://commons.wikimedia.org/wiki/ File:Oak_Ridges_Moraine map.png

Fisher, J. F., and D. H. M. Alexander. 1993. The symbolic landscape of the Oak Ridges Moraine. Environments 22(1): 100104.

Folke, C., S. Carpenter, T. Elmqvist, L. Gunderson, C. S. Holling, B. Walker, J. Bengtsson, F. Berkes, J. Colding, K. Danell, M. Falkenmark, L. Gordon, R. Kasperson, N. Kautsky, A. Kinzig, S. Levin, K. G. Mäler, F. Moberg, L. Ohlsson, P. Olsson, E. 
Ostrom, W. Reid, J. Rockström, H. Savenije, and U. Svedin. 2002. Resilience and sustainable development: building adaptive capacity in a world of transformations. Report for the Swedish Environmental Advisory Council to the Swedish Government, Ministry of the Environment, Stockholm, Sweden.

Folke, C., J. Colding, and F. Berkes. 2003. Building resilience for adaptive capacity in social-ecological systems. Pages $352-387$ in F. Berkes, J. Colding, and C. Folke, editors. Navigating socialecological systems: building resilience for complexity and change. Cambridge University Press, Cambridge, UK. http://dx.doi. org/10.1017/CBO9780511541957.020

Fontana, A., and J. H. Frey. 2000. The interview from structured questions to negotiated text. Pages $645-672$ in K. D. Norman and Y. S. Lincoln, editors. Handbook of qualitative research, Sage Publications, Thousand Oaks, California.

Foster, J. 2005. The social construction of landscape continuity on the Niagara Escarpment and Oak Ridges Moraine: whose continuity? whose landscapes? Dissertation, Faculty of Graduate Studies in Environmental Studies, York University, Toronto, Ontario, Canada.

Gibson, R. B. 2006. Sustainability assessment: basic components of a practical approach. Impact Assessment and Project Appraisal 24(3):170-182. http://dx.doi.org/10.3152/147154606781765147

Gibson, R. B., S. Hassan, S. Holtz, J. Tansey, and G. Whitelaw. 2005 Sustainability assessment: criteria and processes. Earthscan, London, UK.

Gliessman, S. R. 1998. Agroecology: the ecology of sustainable food systems. Second edition, CRC Press, New York, New York, USA.

Gombu, P. 2008. Caledon turf war about urban sprawl. The Toronto Star, 15 June 2008. [online] URL: http://www.thestar. com/news/gta/article/443683.

Greenwood, H., S. Cheuy, Mandala Associates, and M.Slattery. 2010. Headwaters communities in action building a better quality of life together. Economic resiliency in Caledon: a community perspective. Caledon, Ontario, Canada.

Gunderson, L. H., and C. S. Holling, editors. 2002. Panarchy: understanding transformations in systems of humans and nature. Island Press, Washington, D.C., USA.

Gunderson, L. H., C. S. Holling, and S. Light, editors. 1995. Barriers and bridges to the renewal of ecosystems and institutions. Columbia University Press, New York, New York, USA.

Hanna, K. S, S. M. Webber, and D. S. Slocombe. 2007. Integrated ecological and regional planning in a rapid-growth setting. Environmental Management 40:339-348. http://dx.doi.org/10.1007/ s00267-006-0225-7

Hilts, S., S. Lone, and M. Watkins. 2008. Saving the land that feeds us: how to revitalize our near-urban farmland and curb sprawl. Alternatives Journal 34:3.

Historica Research Ltd., Algonquin Associates, Michael McClelland Designs, and Commonwealth Historic Resource Management Ltd. 1994. A cultural heritage resources assessment study for the Oak Ridges Moraine Area. Background study No. 7 to the Oak Ridges Moraine Area Planning Study. Oak Ridges Moraine Technical Moraine Working Committee, Caledon, Ontario, Canada

Holling, C. S. 1973. Resilience and stability of ecological systems. Annual Review of Ecology and Systematics 4:1-23. http://dx.doi. org/10.1146/annurev.es.04.110173.000245

Holling, C. S. 2001. Understanding the complexity of economic, ecological and social systems. Ecosystems 4(5):390-405. http://dx. doi.org/10.1007/s10021-001-0101-5

Igor, P. E. 2002. The Oak Ridges Moraine: evaluation of groundwater resources in the Uxbridge area. Thesis, Faculty of Graduate Studies and Research, Ottawa-Carleton Geoscience Centre and Department of Earth Sciences, Carleton University, Ottawa, Ontario, Canada.

International Association for Impact Assessment (IAIA) and Institute for Environmental Assessment UK (IEA). 1999. Principles of environmental impact assessment best practice. IAIA, Fargo, North Dakota, USA and IEA UK, Lincoln, UK. [online] URL: http://www.iaia.org/publicdocuments/special-publications/ Principles $\% 20$ of $\% 20$ IA_web.pdf

Johnson, S. 2006. Between a rock and a hard place: (re)viewing environmental conflicts over aggregate extraction in exurbia. Dissertation, Faculty Studies and Research, Department of Geography and Environmental Studies, Carleton University, Ottawa, Ontario, Canada.

Lee, K. N. 1993. Compass and gyroscope: integrating science and politics for the environment. Island Press, Washington, D.C., USA.

Lee-Macaraig, C., and L. A. Sandberg. 2007. Assessing municipal lawn care reform: the case of a lawn pesticide by-law in the town of Caledon, Ontario, Canada. Electronic Green Journal 1: 25. [online] URL: http://escholarship.org/uc/item/2js5m5b8

Lei, W. 2009. Flood forecasting in the Oak Ridges Moraine area: comparison of flood frequency analysis methods and integration with web-based spatial decision-making support services. Dissertation, Faculty of Graduate Studies, York University, Toronto, Ontario, Canada.

Liu, J., T. Dietz, S. R. Carpenter, M. Alberti, C. Folke, E. Moran, A. N. Pell, P. Deadman, T. Kratz, J. Lubchenco, E. Ostrom, Z. Ouyang, W. Provencher, C. L. Redman, S. H. Schneider, and W. W. Taylor. 2007. Complexity of coupled human and natural systems. Science, 317:1513-1516. http://dx.doi.org/10.1126/ science. 1144004

Mackenzie, B. F. 2008. Supporting environmental stewardship and livelihood benefits in Ontario's Greenbelt: assessing the potential contribution of the alternative land use services program. Thesis, Faculty of Environmental Studies in Environment and Resources, University of Waterloo, Waterloo, Ontario, Canada.

Markvart, T. 2009. Understanding institutional change and resistance to change towards sustainability: an interdisciplinary theoretical framework and illustrative application to provincialmunicipal aggregate policy. Thesis, Environmental Studies in Environment and Resource Studies, University of Waterloo, Waterloo, Ontario, Canada. 
Matlack, G. R. 1993. Sociological edge effects: spatial distribution of human impact in suburban forest fragmentation. Environmental Management17(6):829-835. http://dx.doi.org/10.1007/ BF02393903

McCarthy, D. D. P. 2006. A critical systems approach to socioecological systems: implcations for social learning and governance.

Dissertations, University of Waterloo, Waterloo, Ontario, Canada.

Ministry of Energy and Infrastructure (MOEI). 2010. Places to grow. Government of Ontario, Toronto, Ontario, Canada. [online] URL: https://www.placestogrow.ca/index.php?lang= eng

Ministry of Municipal Affairs and Housing (MMAH). 2005. Greenbelt plan 2005. Government of Ontario, Toronto, Ontario, Canada. [online] URL: http://www.mah.gov.on.ca/Asset1277. $\underline{\operatorname{aspx}}$

Ministry of Natural Resources (MNR). 1994. Land use patterns on the Oak Ridges Moraine area within the greater Toronto area. Background Study No. 1. Government of Ontario, Toronto, Ontario, Canada.

Ministry of Public Infrastructure Renewal (MPIR). 2006. Places to grow: better choices, brighter future. Growth plan for the greater Golden Horseshoe. Government of Ontario, Toronto, Ontario, Canada. [online] URL: http://www.niagara-gta.com/pdf/Growth\% 20Plan $\% 20$ for $\% 20$ the $\% 20$ Greater $\% 20$ Golden $\% 20$ Horseshoe.pdf

Morrison-Saunders, A. 2011. Principles for effective impact assessment: examples from western Australia. IAIA11 Impact Assessment and Responsible Development for Infrastructure, Business and Industry, 31st Annual Conference of the International Association for Impact Assessment, 28 May-4 June 2011, Puebla, Mexico. [online] URL: http://iaia.org/conferences/ iaia $1 /$ uploadedpapers/final $\% 20 \mathrm{drafts} /$ Principles $\% 20$ for $\% 20$ Effective $\%$ 20Impact $\% 20$ Assessment, $\%$ 20Examples $\% 20$ from $\% 20$ Western $\%$ 20Australia.pdf

Niagara Escarpment Commission. 2005. Niagara Escarpment Planning and Development Act. Niagara Escarpment Commission, Ministry of Natural Resources, Georgetown, Ontario, Canada. [online] URL: http://www.escarpment.org/ landplanning/developmentact/index.php

Niagara Escarpment Commission. 2006. Ontario's Niagara Escarpment. [online] URL: http://escarpment.org/ files/file.php? fileid=fileVdJSIEJhmp\&filename=file_NEP_Plan_Area_Map.jpg

North-South Environmental Inc., Dougan and Associates, and Sorensen Gravely Lowes. 2009. Peel-Caledon significant woodlands and significant wildlife habitat study. Final report, prepared for the Region of Peel and the Town of Caledon, Caledon, Ontario, Canada. [online] URL: http://www.peelregion. ca/planning/officialplan/pdfs/Peel-CaledonSW-SWH-Study-ReportPart4.pdf

Oak Ridges Moraine Land Trust. 2009. Monitoring the moraine. Oak Ridges Moraine Land Trust, King City, Ontario, Canada. [online] URL: http://www.oakridgesmoraine.org/monitor.html

Oak Ridges Moraine Foundation (ORMF). 2003. Oak Ridges Moraine Foundation strategic plan 2003-2006. ORMF, Newmarket, Ontario,Canada.
Oak Ridges Moraine Foundation (ORMF). 2009. Summary of Oak Ridges Moraine Foundation grants. ORMF, Newmarket, Ontario,Canada. [online] URL: http://www.moraineforlife.org/ about/documents/MicrosoftWord-Backgrounder-June2009 000. pdf

Ontario Municipal Board (OMB). 2010. Decision delivered by Susan B. Campbell and Order of the Board, 12 November 2010. Ontario Municicpal Board, Toronto, Ontario, Canada. [online] URL: http://www.coalitioncaledon.com/images/clientupload/OMB $\%$ 20Decision-Rockfort $\% 20$ Quarry,Nov12,2010.pdf

Ontario Municipal Board (OMB). 2011. E-Status Case ROPA 24 Solmar Development Corp. Ontario Municicpal Board, Toronto, Ontario, Canada. [online] URL: http://www.omb.gov.on.ca/ecs/ CaseDetail.aspx?n=PL101408

Peel Agricultural Advisory Working Group (PAAWG). 2011. Report 2010 accomplishments and 2011 work plan. PAAWG, Region of Peel, Ontario, Canada.

Peel Agricultural Advisory Working Group (PAAWG). 2012. Report 2011 activities and revisions to Peel rural quality program guidelines PAAWG, Region of Peel, Ontario, Canada.

Pope, J., D. Annandale, and A. Morrison-Saunders. 2004. Conceptualising sustainability assessment. Environmental Impact Assessment Review 24:595-616. http://dx.doi.org/10.1016/j. eiar.2004.03.001

Province of Ontario. 2006. Oak Ridges Moraine Conservation Act. Government of Ontario, Toronto, Ontario, Canada. [online] URL: http://www.e-laws.gov.on.ca/html/statutes/english/ elaws statutes 01031 e.htm.

Purell, M. 2009. A review of the town of Caledon's official plan relative to conformity with the sustainability aspects of the new provincial policy directions - a discussion paper. The Natural Step Canada, Ottawa, Ontario, Canada.

Region of Peel. 1998. Land report. [online] URL: http://www. peelregion.ca/planning/soe/landreport.htm

Region of Peel. 2010a. Peel Region official plan review adoption of regional official plan amendment 24 places to prosper: growth management, employment areas and greenbelt conformity. [online] URL: http://www.peelregion.ca/planning/officialplan/pdfs/ Ropa24/0323 copy of council report.pdf

Region of Peel. 2010b. What is the official plan. [online] URL: http://www.peelregion.ca/planning/officialplan/whatis-prop.htm

Region of Peel. 2013. Regional boundaries. [online] URL: $\underline{\text { http:// }}$ opendata.peelregion.ca/data-categories/regional-geography/municipalboundaries.aspx

Region of Peel. 2014. Reviewing the Official Plan. [online] URL: http://www.peelregion.ca/planning/officialplan/rev-offplan.htm

Resilience Alliance (RA). 2007. Assessing resilience in socialecological systems: workbook for practitioners. Version 1.0.

Ross, N. 1999. Caledon. Boston Mills Press, Erin, Ontario, Canada.

Save the Oak Ridges Moraine Coalition (STORM). 2007. About STORM. STORM Coalition, Aurora, Ontario, Canada. [online] URL: http://www.stormcoalition.org/pages/about.html 
Sparling, B., T. Asfaha, D. Bucknell, and George Morris Centre. 2008. Statistical profile of agriculture in the Credit River watershed. Prepared for Credit Valley Conservation Authority, Mississauga, Ontario, Canada.

Statistics Canada. 2013. Population by year, by province and territory. Statistics Canada, Ottawa, Ontario, Canada. [online] URL: http://www.statcan.gc.ca/tables-tableaux/sum-som/101/cst01/ demo02a-eng.htm.

Toronto and Region Conservation Authority (TRCA). 2007. Legislative and policy framework. Chapter 2 in TRCA. Planning and development procedural manual. TRCA, Toronto, Ontario, Canada. [online] URL: http://www.trca.on.ca/dotAsset/40097. pdf.

Toronto and Region Conservation Authority (TRCA). 2008a. Humber River state of the watershed report - air quality. TRCA, Toronto, Ontario, Canada. [online] URL: http://www.trca.on.ca/ dotAsset/50109.pdf.

Toronto and Region Conservation Authority (TRCA). 2008b. Humber River state of the watershed report-surface water quantity. TRCA, Toronto, Ontario, Canada. [online] URL: http:// www.trca.on.ca/dotAsset/50155.pdf

Toronto and Region Conservation Authority (TRCA). 2008c. Implementation. Chapter 6 in TRCA. Humber River watershed plan. TRCA, Toronto, Ontario, Canada. [online] URL: http:// www.trca.on.ca/dotAsset/50169.pdf

Town of Caledon. 2007. Town of Caledon Provincial Policy Conformity exercise and 5 year official plan - review analysis of public submissions and recommended work plan. Planning Report 2007-56, Town of Caledon, Caledon, Ontario, Canada.

Town of Caledon. 2008a. Introduction. Chapter 1 in Town of Caledon. Official plan. Caledon, Ontario, Canada. [online] URL: http://www.town.caledon.on.ca/en/townhall/resources/OP2008 Chapter1. pdf

Town of Caledon. 2008b. Secondary plans and other detailed area policies. Chapter 7 in Town of Caledon. Official plan. Caledon, Ontario, Canada. [online] URL: http://www.town.caledon.on.ca/ en/townhall/resources/OP2008 Chapter7.pdf

Town of Caledon. 2008c. Town structure and land use policies. Chapter 5 in Town of Caledon. Official plan. Caledon, Ontario, Canada. [online] URL:http://www.town.caledon.on.ca/en/townhall/ resources/OP2008 Chapter5.pdf

Town of Caledon. 2009a. Provincial policy conformity (PPC) exercise. Council workshop 4 ROPA 24 Growth management, employment lands and greenbelt. Town of Caledon, Ontario, Canada. [online] URL: http://www.town.caledon.on.ca/en/ townhall/resources/PPC-130CT09 Workshop.pdf

Town of Caledon. 2009b. Provincial Policy Conformity (PPC) Exercise Council Workshop \# 1. Town of Caledon, Ontario, Canada. [online] URL: http://www.town.caledon.on.ca/en/ townhall/resources/PPC-06JUL09 Workshop.pdf

Town of Caledon. 2009c. Provincial policy conformity (PPC) exercise. Council workshop \#3 growth management, greenfield density target. Town of Caledon, Ontario, Canada. [online] URL: http://www.town.caledon.on.ca/en/townhall/resources/ PPC-29SEP09 Workshop.pdf

Town of Caledon. 2009d. Town of Caledon draft provincial policy conformity official plan amendment 226. Planning and Development, Town of Caledon, Ontario, Canada. [online] URL: http://www.town.caledon.on.ca/en/townhall/resources/PD-2009-074. pdf

Town of Caledon. 2009e. Town of Caledon Progress Report. Town of Caledon, Ontario, Canada.

Town of Caledon. 2010. The Town of Caledon provincial policy conformity exercise: adoption of official plan amendment 226. Planning and Development, Town of Caledon, Ontario, Canada. [online] URL: http://www.town.caledon.on.ca/en/townhall/resources/ PD-2010-036 FINAL.pdf

Town of Caledon. 2013. Demographics and growth forecasts. Town of Caledon, Ontario, Canada. [online] URL: http://www.town. caledon.on.ca/en/townhall/demographicsgrowthforecasts.asp? mid $=21244$

Town of Caledon. 2014. Town of Caledon official plan. Consolidated 2 June 2014. Town of Caledon, Ontario, Canada. [online] URL: http://www.town.caledon.on.ca/en/townhall/resources/ Official Plan Master Copy - complete.pdf

University of Queensland and University of Southern Queensland. 2008. Building resilience in rural communities toolkit. University of Queensland, Brisbane, Australia and University of Southern Queensland, Toowoomba, Australia. [online] URL: http://www.uq.edu.au/bluecare/docs/toolkit_v5.pdf

Walker, B., L. Perason, M. Harris, K. G. Maler, C. Z. Li, R. Biggs, and T. Baynes. 2010. Incorporating resilience in the assessment of inclusive wealth: an example from south east Australia. Environmental Resource Economic 45:183-202. http://dx.doi. org/10.1007/s10640-009-9311-7

Walker, B., and D. Salt. 2006. Resilience thinking. Island Press, Washington, D.C., USA.

${ }^{[1]}$ One interviewee declined audio recording. Another interview was not audio recorded because of technical problem. 


\section{Appendix 1. A glossary of Ontario legislation related to conservation and urban growth affairs}

\section{Niagara Escarpment Planning and Development Act}

The act was passed to ensure the protection of the escarpment, and to provide policies for land use and development criteria. It establishes procedures for development control appeals and hearings.

\section{Oak Ridges Moraine Conservation Act}

The act was passed to protect the ecological and hydrological integrity of the Oak Ridges Moraine area. The implementation piece of the act is known as the Oak Ridges Moraine Conservation Plan which provides land use and resource management direction within the moraine.

\section{Greenbelt Act}

The act enables the creation of the Greenbelt Belt Plan which protects 1.8 million acres of agricultural land and some environmentally sensitive areas around the Greater Golden Horseshoe, including the Oak Ridges Moraine and Niagara Escarpment.

\section{Planning Act}

The act details the provincial interest and municipal regulatory powers in land use. Within the Planning Act is the Provincial Policy Statement which contains key concepts regarding ecosystems and watersheds, ecological functions and natural connections.

\section{Conservation Authorities Act}

The act establishes and governs 36 conservation authorities in Ontario to carry out watersheds and lands management and restoration programs to address issues like erosion and flood control.

\section{Places to Grow Act}

The act coordinates a strategic direction for population growth and development in Ontario that aims to support economic prosperity, environmental protection and community building. Regional growth plans are developed based on the act. 


\section{Appendix 2. Elaborations on desirable qualities of Caledon by interviewees}

\section{Natural Landscape \& Heritage (10)}

Ten interviewees said that they appreciated the natural landscape and heritage of Caledon. Environmental group leader (EG) 1 said that, "I love the variability of the terrain, the hills, and the creeks, the ponds and the bushes, Maple bushes, and trees." EG 2 said that, "What I also appreciate about Caledon is the fact that can be surrounded by trees, and hills, and water, and coyotes [a species of wolf] are virtually in the next fields." An individual (IN) 1, who has lived in Caledon for more than 40 years responded that, "fresh air, its [Caledon] history, its prehistory, particularly, it's quite stunning." Politician (PL) 2 appreciated the terrain, the Bruce trails and the Trans-Canada trails.

\section{Engaged Citizens (6)}

Individual (IN) 1, who has lived in Caledon for 40 years, pointed out that, "One of the good things about Caledon is that people are very naturally environmentally conscious. So you have a lot of people who support Council, support initiatives to conserve the Escarpment, the Moraine." Environmental group leader (EG) 1 added, "I appreciate that there are so many organizations that deal with environmental issues." EG 3 mentioned, "I feel that a lot of people in the community really care about it, and are actively trying to make it a good community."

Politician (PL) 1 observed that, "the people are well-informed and they know about what's going on. They are very knowledgeable and for the most part, very interesting and interested in what's going on.” PL 2 emphasized that,

from a community standpoint, I really love the people of Caledon. They are engaged, well informed, and involved in their Town. They don't sit quietly in the back row; you hear from them. They tell you what they think. They are right in there. I love that. I really do like that. They put a lot of pressure on all levels of government and that's good.

\section{Rural setting with urban benefits (5)}

Five interviewees pointed out that many people wanted to have a rural environment, but they also wanted to enjoy the urban benefits such as 24-hour grocery and diverse cuisines. Municipal staff (MS) 1 mentioned "I think, well, probably, you actually have country here. But you have a fair amount of urban benefits. Some of the things I enjoy - golf, food, stuff like that..." Individual (IN) 3 said, "I could be Mr. Business Man in downtown Toronto in my suit, and then come home and put on my old clothes and jump on my tractor."

Environmental group leader (EG) 5 added, "I must say I love the trail ways... I have a nice shop, grocery centre, supermarket in Caledon East. And this is a 24-hour one. That is a good thing." But EG 5 also recognized that many residents wanted a rural lifestyle and urban benefits, and that could be conflicting.

\section{Family Roots, Small Town Character \& Caring Municipality $(3,2,1)$}

Three interviewees said that they value family roots and the small town character of Caledon. Politician (PL) 1 said, "And it's always the community and the families that bring what I would call the life to earth, the life within our community and our country here." An aggregate industry representative 
(AI) said, "So I have a lot of family connections. My grandparents lived in Alton during World War Two. So I appreciate my personal family history."

Two interviewees said that they appreciated the small town character of Caledon. Individual (IN) 2 said, "I like the feeling of small community, and all the people I know who are well involved in the community. And I went for a bike ride once down at the rail trail, and I would say I met seventeen different groups of people. All of them we knew." Environmental group leader (EG) 2 said, "And I appreciate the fact there is a scale-down sense of, like shopping. So there is a vibrant kind of shopping area, but it's all scale-down." EG 2 added, "And I appreciate the fact that we do have a very open and caring municipal government, both whether it's politicians or staff. That staff truly reflect a certain flavour of Caledon. And that comes out of the Official Plan."

Note: Identity codes of interviewees

AI=Aggregate Industry; EG=Environmental Groups' Leaders; LPD=Local Property Developer; MS= Municipal Staff; PL=Politicians; IN=Individuals; SS=Social Services 


\section{Appendix 3. Identified resilience assets and associated interview quotes Strong local civic engagement and effective volunteerism}

- MS 5"If you do something wrong, they are certainly there to correct us. I guess the best example of it, we do have a committee, the Caledon Environment Advisory Committee. So they've, basically, in every project that the Town, Caledon is taking, they will review it, and they will provide comments, support us or correct us. We have also been partnering with the Countryside Alliance on different initiatives."

- IN1"Life would not be so great here if we didn't have this huge core of volunteers that supported Council and staff on doing things."

- EG1 "The strengths are again all those organizations that bring all the people together, and help them to have a stronger voice about what's going on."

- EG2 "Over the last 20 years, a group of people are there to protect and volunteer to preserve its ecological and environmental assets."

- SS "Probably, there are a lot of advocacy, groups, environmental groups, people passionate about the community. So I think the community itself is a main strength, the people."

- PL4 "Since 1970, greater awareness in society causes legislation, which is all part of awareness, has made us pay more attention to the balance between nature and people."

\section{Participatory planning and solid citizen-municipality relationship}

- MS3 "Well, they [residents] get very involved in growth planning. And pushing Council to control growth."

- EG 2 "I think that one of the strengths is the fact the relationship between the municipal government, whether it's politicians or staff, and citizenry. It's a pretty solid relationship."

- EG 4 "The whole tri-nodal process, the whole Master planning process, that all came out of CEAC [Caledon Environmental Advisory Committee]."

- EG5 "He [Councillor] just won the election. I must say they are willing to working with community, to a large extent."

\section{Low-impact urban development as an opportunity}

- MS 1 'I used the word 'low-impact' in the sense that because people say you can't do anything, you know, and I think we need to get beyond that."

- MS 3 "So we have a lot of areas protected, we have a lot of requirements for developers doing development. Where we need to sort of take the next step is low-impact development...I think one of the great opportunities is that we are starting from scratch. We have the opportunity to do things right, not to have repeat mistakes... Given the amount of technology that exists now, and the amount of attention paid to the environment, I think we have the opportunity to create a community that is based on good foundation of sustainability in growth management practices."

- MS 5 "To make Caledon resilient and sustainable is to protect our natural landscapes through sustainable rural/agricultural uses and balanced urban growth centres based on low impact design principles"

- PL 3 "Low-impact development is the way we have to start thinking... You know what, we can bring the population in. Let's think about how it fits into the nature around it, make it fit for what we need."

- PL5 "I think, the strength in society, is that if you can have people to work and live within a ten and fifteen-minute range from home is a very strong, strong thing in our society today 
where people enjoy where they live and work. So I think again planning, planning has to do with a big part of that."

- IN 2 "It's almost a battle between long-time residents and developers. And I don't think it has to be that way...Maybe the European models or other models where they managed to get some growth without destroying things"

\section{Diversified agriculture}

- PL2 "There are some goat farms starting up too, I think we can expect to see a growing diversity in livestock."

- MS1 "But you know, allowing more value-added on the farm, right? Looking at, you know, other areas where recreation can be supported with additional facilities."

- PL 4 "And they [Downy farm] also sell fresh turkeys, as you can see there, fresh turkeys, ducks in the winter time... There is a building in the back where they [Downy Farm] make their own wine, fruit wines which they sell."

- EG2 "They [several Caledon residents] have really big, big plans to really make this a multipurpose venture where they grow vegetables, they will have a CSA [Community Support Agriculture] but they really see it as a way to try work for youth to teach about the connections and environmental issues and local food security. So that's a really cool thing. That's a huge asset to have those kind of people who are so motivated and self-directed"

\section{Provincial conservation policies}

- IN 3 "An asset is defined legislation that is environment-focused, lifestyle-focused, which I think the Oak Ridges Moraine, Niagara Escarpment Commission and Greenbelt Plan."

- EG 4 "And they got the Niagara Escarpment Plan, the Oak Ridges Moraine Plan, and we got the Greenbelt Plan. So there is a large swap of Caledon that is pretty well protected."

- PL5 "I think really it's the policies of the government and the Official Plans uphold their policies, then I think that the ability of maintaining farming lifestyle can live in Caledon."

\section{Municipal Environmental Leadership}

- MS 3"Council sees fit to maintain a fairly large Planning Department here for the size of the municipality. And so, they put a lot of resource into growth management."

- PL2 "We have some pretty stringent environmental policies and we have taken major steps forward. We have an Environmental Progress Officer who monitors and reports on our successes."

- MS 4 "Engaged citizens and environmental leadership, I see them as assets. In the [Environmental Progress Action Plan], there is a whole section in the first part of the Plan on community's achievements and Town's achievements".

Note: Identity codes of interviewees

EG=Environmental Groups' Leaders; LPD=Local Property Developer; MS= Municipal Staff;

PL=Politicians; IN=Individuals; SS=Social Services 


\section{Appendix 4. Identified resilience threats and associated interview quotes}

\section{Urbanization and population growth}

- MS 2 "The white belt [areas subject to new development] that has been established by the provincial government will certainly be bringing a lot more industrial development through the southern, through at least the community. So that its' a threat because I think that will certainly change a big chunk of the town, and bring with it huge transportation system along with that."

- MS 3 "The Greenfield density target is kind of, the problem with it is top-down planning, and it's planning with numbers... the Province's requirement that it's a combined target between residential and employment. It can force the residential density way, way up to 60,70 or even 100 persons per hectare, just to compensate for some of the employment land."

- PL4 "We continue to urbanize all the good agricultural land, we continue to green up the non-agricultural land as a compensator for urbanization, but we don't do anything about agriculture. We continue, as society, to rely on more marginal lands' ability to produce more food. And in doing that, we are relying on more and more fertilizers, fairly dangerous methodology."

- MS 1 "But probably the threats are more to what we may call heritage vistas. That's what I think with development, right? You go to some places and you can see for miles, and it's beautiful, right? You change that into a couple square mile of housing. It doesn't look as interesting anymore."

- PL 5 "And the sadness I think that I see is generations will suffer from is the amount of, of urban pressure that you have that takes away those family lifestyles. To urban growth and growth of the country."

- IN 1 "I do not believe it's appropriate for developers to take us on the OMB, the Ontario Municipal Board, or Councillors to undermine something [Caledon's Official Plan] which the rest of Council has made a decision on... You know my tax money, my time, my effort went to, hundreds of people like me, went towards creating a good Official Plan and area plans."

Disconnect between provincial conservation legislation and local people's livelihoods and stewardship

- $\quad$ PL2 "And they [bureaucrats] keep bringing down regulations after regulations after regulations about environmental ones as well as others on what you can do and what you can't do. And it appears to me to be a group of bureaucrats sitting down at Queen's Park who have never been out in the countryside in their lives. And they don't really know what's going on. And therefore, they are making it much more difficult for these people [farmers] to make a living. They are selling. They are selling [the farmland]."

- PL3 "And they come up with regulations. The big thing is that they think because they are looking at textbook, they can think better. Why don't they ask people for their input?

- MS 3 "Their lack of flexibility in the Oak Ridges Moraine Act prevented it [heritage conservation], and within two years, the barn had burned down, and they had knocked down the farmhouse."

- EG2 "I mean so much of the Moraine in Caledon is in the natural linkage. Really, you can't do anything there. There's no institutional use... I have always wanted to convert our family farm into a centre for learning. But in order to run that through, a charitable organization and formalize it, one would need to have it zoned institutional."

\section{Decline in agriculture}

- IN 1"In Caledon, we have the top-grade farmland, but we have the only farmland left. It is getting huge development pressure from the east and from the south."

- PL 2 "Agriculture is suffering, it used to be our main industry in Caledon. With provincial policies and planning regulations like Places to Grow, the Oak Ridges Moraine Act and the Greenbelt Act, it makes it very difficult for farmers to expand their operations or adapt to changing markets." 
- PL4 "So it's not only agriculture getting threatened, it's all the support industries, employment towards agriculture get equally threatened. So the impact on our economy is much, much larger than it seems simply because a farmer is not farming."

- PL5 "And that agriculture is probably one that suffers most and lost from all of the industries that we have."

\section{Aggregate extractions}

- EG 5 "And of course they are a threat to our water supply. And all the other things that came with that, the dust, many issues."

- PL4 "So the urbanization demands of Ontario makes the aggregates very attractive. So the laws of Ontario favour the gravel companies. The municipalities and the people who live within the area, and their municipal governments are always pitted against the gravel"

- IN3 "Obviously, the gravel industry is definitely a threat. You think you are living on a quiet country road, and you may end up having a large volume of gravel trucks goes by. There could be noise, dust."

- IN6 "I can show you gravel pits down there that has trees, big, growing in the middle of them. How long did a tree grow that big? People don't understand that very question. Why didn't they rehabilitate?"

\section{Fiscal challenges}

- PL2 "So when you get a developer who said I want to go right now, I am putting another 27,000 people in. Oh no, you are not. Because the 60,000 people over the next 10 years cannot afford to pay 86 million."

- PL5 "And then the next thing is to find the water, to find the water and the sewage capacity to serve that new growth. And build that infrastructure and the money to do that, and keep taxes at a reasonable rate."

- MS3 "One thing that is an issue is that the Town's assessment base is very heavily residential as opposed to partial industrial. And people think that it's fiscally beneficial to have a better balance between residential and industrial, and not residential assessment. Our Fiscal Impacts Study communicated that it's not necessarily that simple because there's some industrial uses, low industrial uses, that don't pay for themselves."

Note: Identity codes of interviewees

EG=Environmental Groups' Leaders; LPD=Local Property Developer; MS= Municipal Staff; PL=Politicians; $\mathrm{IN}=$ Individuals; $\mathrm{SS}=$ Social Services 


\section{Appendix 5. Trade-off rules}

1. Maximum net gains (Gibson et al., 2005; Pope et al., 2004)

Seek to attain mutually reinforcing, cumulative and lasting contributions that bring the most positive overall results in sustainability (including ecological, social and economic aspects)

2. Burden of argument on trade-off proponent (Morrison-Saunders, 2011; Gibson et al., 2005)

Burden of proof rests on the proponent of the trade-off who has to prove that the trade-off is unavoidable and acceptable

3. Avoidance of significant adverse effects (Gibson et al., 2005; Gibson, 2006)

No trade-off that causes significant adverse effects on any sustainability areas (ecological, social, economic) can be justified uncles the alternative is worse

4. Protection of the future (Gibson et al., 2005; Morrison-Saunders., 2011)

No displacement of significant adverse effects from the present to the future can be justified unless the alternative is of an even more significant adverse effect

5. Open Process (IAIA \& IEA 1999; Morrison-Saunders., 2011; Gibson et al., 2005)

Proposed trade-offs must be addressed through open involvement of all stakeholders, particularly those who will be affected by the trade-offs

The trade-off rules mentioned above are retrieved from researches on sustainability and environmental assessments (Gibson et al., 2005; Gibson, 2006; IAIA \& IEA 1999; MorrisonSaunders., 2011; Pope et al., 2004). Yet, the trade-off rules have the potential to be applied in situations where people need to resolve conflicts and enhance the resilience of social-ecological systems. The application of trade-off rules will differ in various circumstances and contexts. It is important to recognize the specific circumstances and priorities. In some cases, the greatest threat is the exploitation of natural resources while in another case; a greater concern is corruption and poverty (Gibson et al., 2005). Hence, the application of trade-off rules "will not always lead to the same conclusions about what trade-offs should be accepted or rejected" (Gibson et al., 2005: 138). For instance, it will be acceptable to allow job losses to reduce resource exploitation, but it will not be acceptable if the most poor will lose their jobs (Gibson et al., 2005). Therefore, the application of trade-off rules must attune to local circumstances and contexts. 